\title{
14. WHOLE-ROCK OXYGEN AND CARBON ISOTOPE STRATIGRAPHY OF THE PALEOGENE AND CRETACEOUS/TERTIARY BOUNDARY IN HOLE 807C ${ }^{1}$
}

\author{
Richard M. Corfield ${ }^{2}$ and Julie E. Cartlidge ${ }^{2}$
}

\begin{abstract}
Whole-rock $\delta^{18} \mathrm{O}$ analyses of the Paleogene and Upper Cretaceous succession at Ocean Drilling Program Hole 807C suggest the presence of hiatuses between 876.95 and $894.47 \mathrm{mbsf}$ and between 1138.82 and $1140.94 \mathrm{mbsf}$. The $\delta^{13} \mathrm{C}$ data show a pronounced positive excursion between 1130 and $1180 \mathrm{mbsf}$ that corresponds to the positive $\delta^{13} \mathrm{C}$ values characteristic of the Paleocene. Despite the stratigraphic breaks in the section, the $\delta^{18} \mathrm{O}$ data show a systematic increase between $1360 \mathrm{mbsf}$ and the hiatus between 876.95 and 894.47 mbsf, which is consistent with previous suggestions of long-term climatic cooling through the Paleogene. The Cretaceous/Tertiary transition is apparently complete in this section and is of remarkable thickness. The expanded nature of this portion of the succession is probably the result of secondary depositional processes. High-resolution sampling across this boundary may reveal detailed structure of the $\delta^{13} \mathrm{C}$ decline associated with the extinctions that mark the termination of the Cretaceous.
\end{abstract}

\section{INTRODUCTION}

Ocean Drilling Program (ODP) Leg 130 Holes 807A and 807C together form a composite section penetrating Neogene, Paleogene, and Cretaceous sediments on the flank of the Ontong Java Plateau. The upper part of the section consists of foraminiferal and nannofossil chalk that grades into limestone at approximately $1000 \mathrm{~m}$ below sea floor (mbsf). We made whole-rock $\delta^{13} \mathrm{C}$ and $\delta^{18} \mathrm{O}$ measurements throughout the Paleogene and Cretaceous intervals of this section to assist in the identification of stratigraphic breaks and the documentation of paleoceanographic trends. In particular, we concentrated on the Cretaceous/Tertiary transition. The lithified nature of the Paleogene and Cretaceous does not presage well for detailed Cretaceous/Tertiary boundary studies in comparison with such sites as Deep Sea Drilling Project (DSDP) Site 577 (Zachos et al., 1985) or Hole 690B (Stott and Kennett, 1990). However, Hole 807C was drilled in a graben, and, as shown in this study, the unique sedimentological setting of this site may yield an exceptionally detailed record of the Cretaceous/Tertiary boundary transition.

\section{METHODS}

The $\delta^{13} \mathrm{C}$ and $\delta^{18} \mathrm{O}$ stratigraphies generated by the analysis of whole-rock samples were used to identify discontinuities that might be a result of the presence of hiatuses. Samples were drilled from limestone chips using a vibrotool, cleaned using $10 \%$ hydrogen peroxide and acetone, and then dried for $30 \mathrm{~min}$ at $60^{\circ} \mathrm{C}$. The samples were analyzed isotopically using a VG Isotech PRISM mass spectrometer with an on-line VG Isocarb carbonate preparation system in the Oxford laboratory. The mass spectrometer is calibrated to PDB daily by means of an in-house carbonate standard (NOCZ), which is calibrated regularly to NBS 19 . Reproducibility of replicate standards was better than $0.1 \%$.

\section{RESULTS AND DISCUSSION}

Figure 1 shows the $\delta^{13} \mathrm{C}$ and $\delta^{18} \mathrm{O}$ whole-rock stratigraphy of the composite Paleogene section of Holes 807A and 807C (data in Appendix). The $\delta^{18} \mathrm{O}$ record in particular is useful for the identification of

\footnotetext{
'Berger, W.H., Kroenke, L.W., Mayer, L.A., et al., 1993. Proc. ODP, Sci. Results, 130: College Station, TX (Ocean Drilling Program).

${ }^{2}$ Department of Earth Sciences, University of Oxford, Park's Road, Oxford OX1 3PR, United Kingdom.
}

hiatuses because of its systematic change over the interval from the base of the measured section (1360 mbsf) to a major discontinuity between 876.95 and 894.47 mbsf (Samples 130-807C-12R-1, $35-37 \mathrm{~cm}$, and $-15 \mathrm{R}-1,57-59 \mathrm{~cm}$ ). This generally monotonic trend is probably the local expression of the long-term Cenozoic cooling documented in foraminifers by previous authors (e.g., Savin, 1977; Corfield et al., 1991). The discontinuity marked "A" between 876.95 and 894.47 mbsf is not obviously connected to evidence of a hiatus from the shipboard biostratigraphy (Shipboard Scientific Party, 1991), but this may be because of the relative scarcity of biostratigraphic datums within this interval of the core. Also, this level in Hole 807C is characterized by poor recovery of sediment.

Another discontinuity (marked " $\mathrm{B}$ ") occurs in the $\delta^{18} \mathrm{O}$ record between 1138.82 and 1140.9 mbsf (between Samples 130-807C-46R-3, $62-64 \mathrm{~cm}$, and $-47 \mathrm{R}-1,70-72 \mathrm{~cm}$ ). Shipboard biostratigraphic data do not suggest the presence of a hiatus at this level in the hole. However, this may be caused by the difficulties of assigning age determinations in limestone with a low abundance of marker species.

The interval between 1138.82 and $1188.8 \mathrm{mbsf}$ (130-807C-46R-3, $62-64 \mathrm{~cm})$ and $1180 \mathrm{mbsf}(130-807 \mathrm{C}-54 \mathrm{R}-1,0-2 \mathrm{~cm})$ exhibits very positive $\delta^{13} \mathrm{C}$ values. This interval is within the Paleocene, as determined by the shipboard biostratigraphers, and the isotopically positive values are entirely typical of this interval (Shackleton and Hall, 1984; Shackleton et al., 1985; Stott et al., 1990; Corfield et al., 1991). Figure 2 illustrates this portion of the core in more detail as well as the Cretaceous/Tertiary boundary and the Late Cretaceous.

Premoli Silva (this volume) has identified a stratigraphic break (marked "C" on Fig. 2) between planktonic foraminiferal Zones P11 and P5 between 1160.24 and 1161.26 mbsf (between Samples 130807C-51R-1, 3-5 cm, and $-51 \mathrm{R}-1,105-107 \mathrm{~cm})$. Our $\delta^{13} \mathrm{C}$ data do not unequivocally support this interpretation however. The $\delta^{13} \mathrm{C}$ signal across this portion of the core shows the monotonic decline characteristic of the upper Paleocene/Paleocene-Eocene boundary interval. The gap suggested by the biostratigraphy of Premoli Silva is approximately $10 \mathrm{~m} . \mathrm{y}$. (between 58 and $48 \mathrm{Ma}$ ) using the time scale of Berggren et al. (1985). This interval is characterized by a $\delta^{13} \mathrm{C}$ decline toward the $\delta^{13} \mathrm{C}$ minimum at or near the Paleocene/Eocene boundary, followed by a recovery to values intermediate between the ${ }^{13} \mathrm{C}$ maximum of the late Paleocene and the minimum near the Paleocene/Eocene boundary. The whole-rock $\delta^{13} \mathrm{C}$ stratigraphy from DSDP 527 illustrated by Shackleton et al. (1985, fig. 4) shows that at $48 \mathrm{Ma} \delta^{13} \mathrm{C}$ values were at about approximately $2 \%$; 10 m.y. earlier (at $58 \mathrm{Ma}$ ) $\delta^{13} \mathrm{C}$ values from the same site were similar. Hence, no unique $\delta^{13} \mathrm{C}$ value for this interval is present that would discriminate 

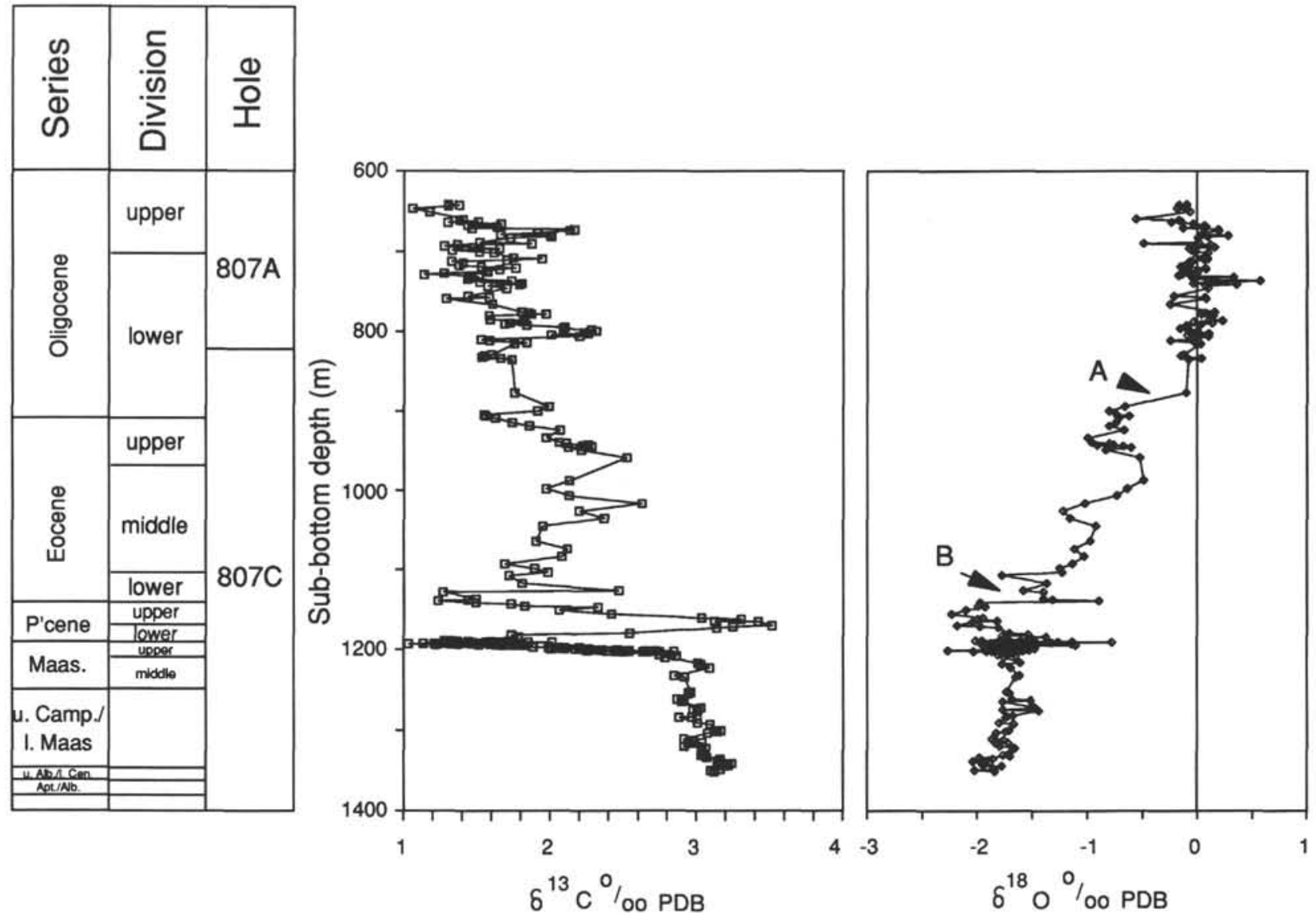

Figure 1. Oxygen and carbon isotope stratigraphy of the Paleogene and Cretaceous of Holes 807A and 807C. $\mathrm{A}=$ possible hiatus between 876.95 and 894.47 mbsf, $B=$ possible hiatus between 1138.82 and $1188.8 \mathrm{mbsf}$.

between the two possibilities. However, as Figure 1 shows, $\delta^{13} \mathrm{C}$ values continue to decline after the interval between Samples 130-807C-51R$1,3-5 \mathrm{~cm}$, and $-51 \mathrm{R}-1,105-107 \mathrm{~cm}$. This decline may be the local manifestation of the continuing $\delta^{13} \mathrm{C}$ decrease known from other sections to be characteristic of the early Eocene. If this is the case, then it is unlikely that the biostratigraphic assignment of sediments up to 1127.24 (Sample 130-807C-45R-2, $64 \mathrm{~cm}$ ) where the possible hiatus marked "B" occurs, are really from planktonic foraminifer biozones P11 through P12/P13. This discrepancy may be reconciled by the fact that this portion of Hole $807 \mathrm{C}$ is known to be heavily reworked (Fig. 1; Premoli Silva, this volume); and, as she points out, because of the pervasive resedimentation in this part of the hole, zonal assignments are tentative. The $\delta^{18} \mathrm{O}$ data also fail to show a discontinuity at this level that might support the presence of a hiatus.

Premoli Silva (this volume) also suggests the possibility of a hiatus (marked "D" on Fig. 2) between 1184.49 and 1185.51 mbsf between planktonic foraminiferal Zone P3 and Subzone P1b (Samples 130807C-53R-4, 58-60 cm, and $-53 R-5,10-12 \mathrm{~cm}$ ). Both the $\delta^{13} \mathrm{C}$ and the $\delta^{18} \mathrm{O}$ data indicate a disjunction that might support this hypothesis. Further biostratigraphic and chemostratigraphic work at a higher sample spacing is clearly required to resolve these differences.

\section{The Cretaceous/Tertiary Boundary at Hole 807C}

We significantly increased our sampling resolution across the Cretaceous/Tertiary boundary at Hole $807 \mathrm{C}$ based on the identification by shipboard biostratigraphers of the Thoracosphaera bloom that is characteristic of the immediate aftermath of the boundary interval (Pospichal and Wise, 1990). In addition, we used the biostratigraphic data of Premoli Silva (this volume), which provides further constraints on the stratigraphy of this portion of Hole $807 \mathrm{C}$. Premoli Silva (this volume) places the Cretaceous/Tertiary boundary between Samples 130-807C-55R-1, 49-50 cm, and -55R-1, 35-36 cm (1197.39 and $1197.25 \mathrm{mbsf}$ ) on the basis of the first occurrence (FO) of Tertiary planktonic foraminifers. Hence, a median estimate of the position of this boundary is at Sample 130-807C-55R-1, 42-43 cm (1197.32 mbsf). Premoli Silva (this volume) further estimates the FO of Subbotina pseudobulloides (which according to the zonal scheme of Berggren and Miller [1988] defines the base of planktonic foraminifer Subzone P1a) to lie at Sample 130-807C-54R-4, 148-149 cm (1194.78 mbsf). This is consistent with the placement by Mao and Wise (this volume) of the FO of Coccolithus pelagicus (within nannofossil Subzone CP1b) at Sample 130-54R-3, $90 \mathrm{~cm}$ (1192.7 m). Using the FO of Danian planktonic foraminifera and the FO of $S$. pseudobulloides, we calculate a median thickness for this interval of $2.54 \mathrm{~m}$. Using the time scale of Berggren et al. (1985), this yields a sedimentation rate for this part of Hole $807 \mathrm{C}$ of $12.7 \mathrm{~m} / \mathrm{m}$.y. We note, however (Premoli Silva, this volume), that problems exist in unequivocally assigning zonal boundaries because of the lithified nature of the sediment. As Table 1 shows, this is the highest sedimentation rate documented of several intensively studied Cretaceous/Tertiary boundary sections, with the possible exception of DSDP Site 524 (Hsü et al., 1982). We note that our sedimentation rate estimate of $12.7 \mathrm{~m} / \mathrm{m}$.y. for the Cretaceous/Tertiary transition at Hole $807 \mathrm{C}$ is similar to the independent estimate of $14 \mathrm{~m} / \mathrm{m}$.y. based on paleomagnetic data (J.A. Tarduno, pers. comm., 1992; Corfield et al., this volume). Thus, although Hole 807C is in limestone facies, the potential to resolve closely spaced chemostratigraphic and biostratigraphic events exists at this site, provided it can be demonstrated that the sediments have not been too distorted by secondary sedimentation.

Figure 3 illustrates our $\delta^{13} \mathrm{C}$ and $\delta^{18} \mathrm{O}$ data from the Cretaceous/ Tertiary boundary interval at Hole $807 \mathrm{C}$. The $\delta^{13} \mathrm{C}$ decline noted by 


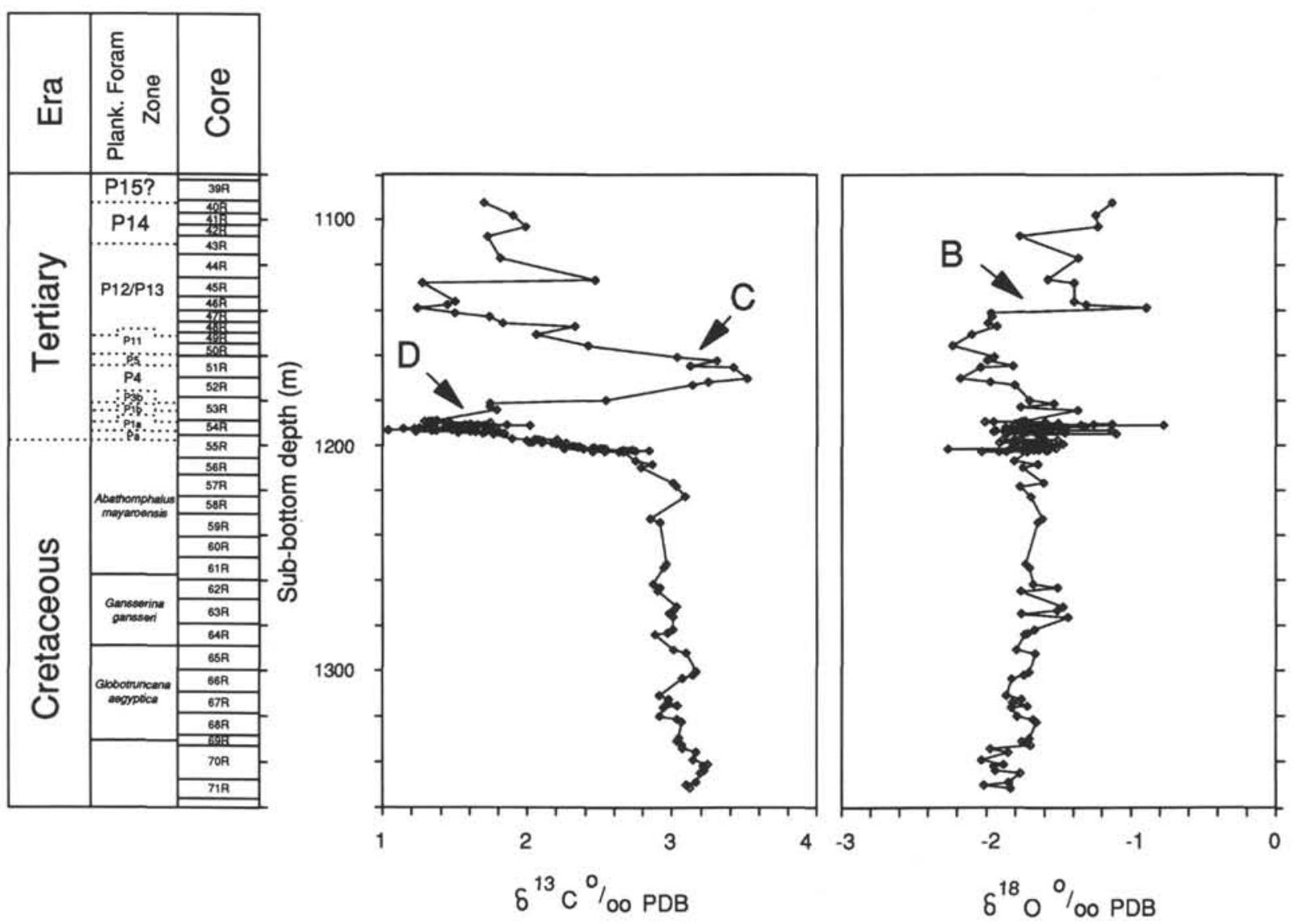

Figure 2. Oxygen and carbon isotope stratigraphy of the Paleocene and Upper Cretaceous of Hole 807C. Note the isotopically positive values characteristic of the Paleocene epoch. Hiatus B is identified; $\mathrm{C}$ and D $=$ possible hiatuses inferred from lack of identifiable foraminiferal zones (Premoli Silva, this volume).

authors at several different sites (e.g., Scholle and Arthur [1980], Renard [1986], and Corfield et al. [1991] at the Bottaccione Gorge section in Italy; Shackleton and Hall [1984] at DSDP Site 527; Zachos and Arthur [1986] at DSDP 577; Stott and Kennett [1990] at ODP Hole 690B) is clearly discernible at Hole $807 \mathrm{C}$. In addition, because of the high sedimentation rates in the Cretaceous/Tertiary boundary interval at Hole $807 \mathrm{C}$, the $\delta^{13} \mathrm{C}$ decline occurs over a thickness of $9.23 \mathrm{~m}$. This is probably the most expanded Cretaceous/Tertiary $\delta^{13} \mathrm{C}$ decline yet documented.

Clearly, it is imperative to understand how such a thick Cretaceous/Tertiary boundary section could have been deposited and whether such a section can be regarded as stratigraphically continuous and sedimentologically undisturbed. The high sedimentation rates calculated for the Cretaceous/Tertiary boundary interval at Hole 807C strongly suggest that deposition was not primary. W.H. Berger (pers. comm., 1991) has suggested that sedimentation rates at Hole 807C were significantly enhanced during this interval as a result of winnowing of the sediment cover surrounding the graben. The increased flux of sediment into the graben would result in significantly higher sedimentation rates because of the confined nature of this small sedimentary basin. Support for this hypothesis comes from the biostratigraphic data of Premoli Silva (this volume) and Sliter and Leckie (this volume), who identified both size and shape sorting of planktonic foraminifers from thin sections that suggest winnowing. As well as size and shape sorting, Premoli Silva (this volume) has identified turbiditic layers within the Cretaceous/Tertiary succession at Hole $807 \mathrm{C}$. We have plotted these intervals of sedimentological disturbance on Figure 3. The setting of the Cretaceous/Tertiary boundary at this site is further discussed in Corfield et al. (this volume).
In addition to this peculiar sedimentological environment, evidence is present for stylolitization within this portion of Hole $807 \mathrm{C}$. The sediment compression implied by stylolitization suggests the probability that carbonate-bearing pore fluids might have been mobilized, possibly leaching sediment from one part of the core and depositing it elsewhere in the form of carbonate cement. However, the presence of stylolites is patchy within the Cretaceous/Tertiary boundary section of Hole $807 \mathrm{C}$ and is limited at most to centimeter-scale occurrence. Thus, we consider it unlikely that this process could have affected the whole 9.23-m thickness of the $\delta^{13} \mathrm{C}$ decline at the Cretaceous/Tertiary boundary at Hole $807 \mathrm{C}$. Diagenetic complications of the $\delta^{13} \mathrm{C}$ signal are further discussed in Corfield et al. (this volume).

Given the pervasive influence of foraminiferal resedimentation from winnowing and turbidity currents within the boundary interval at Hole $807 \mathrm{C}$, it is possible that the monotonic decline in $\delta^{13} \mathrm{C}$ over this $9.23-\mathrm{m}$ interval is a result at least in part of secondary depositional processes, and therefore that the record is not a reliable portrait of events. Reworking of fine-fraction calcite could result theoretically in the transposition of heavy (Cretaceous) $\delta^{13} \mathrm{C}$ values to higher (Danian) levels in the core if the ratio of reworked material to material in primary position were high and the reworked material were significantly older than the primary material. To rework the entire $9.23-\mathrm{m}$ thickness of the Cretaceous/Tertiary boundary carbon isotope depletion at Hole $807 \mathrm{C}$ would require the mixing of older material relatively enriched in ${ }^{13} \mathrm{C}$ with younger material relatively depleted in ${ }^{13} \mathrm{C}$, and its amalgamation into micrite, which would possess an average $\delta^{13} \mathrm{C}$ composition. We note, however, that the $\delta^{13} \mathrm{C}$ record across the Cretaceous/Tertiary boundary at Hole $807 \mathrm{C}$ proceeds remarkably uniformly, a feature not necessarily predicted by the episodic rework- 
Table 1. Comparative sedimentation rates across selected DSDP and ODP Cretaceous/Tertiary boundary sections.

\begin{tabular}{cc}
\hline Hole & $\begin{array}{c}\text { Sedimentation rate } \\
(\mathrm{m} / \mathrm{m} . \mathrm{y} .)\end{array}$ \\
\hline DSDP 577 & ${ }^{1} 1.95$ \\
DSDP 524 & ${ }^{2} 66.60$ \\
DSDP 527 & ${ }^{3} 5.00$ \\
ODP 690C & ${ }^{4} 2.50^{*}$ \\
ODP 689B & ${ }^{4} 1.00^{*}$ \\
ODP 807C & 12.70
\end{tabular}

Notes: Estimates based on depth difference between the Cretaceous/ Tertiary boundary and the FO of Subbotina pseudo-bulloides (K/T boundary in this case is defined by the FO of Danian planktonic foraminifers except where marked with an asterisk $(*)$, in which case the boundary is defined by the LO of Cretaceous planktonic foraminifers).

${ }^{1}$ Date from Gerstel et al. (1986), but also see discussion by Corfield and Shackleton (1988).

${ }^{2}$ This high value is almost certainly the result of the poor depth uncertainties associated with the planktonic foraminifer age control points over this interval in DSDP Hole 524. Note, however, that Hsü et al. (1982) claimed very high rates of $30 \mathrm{~m} / \mathrm{m}$.y. for this site on the basis of other sedimentation rate constraints.

${ }^{3}$ Data from Boersma (1984).

${ }^{4}$ Data from Thomas et al. (1990).

ing of older material suggested by size and shape sorting of foraminifers. In addition, if secondary sedimentation from the region around the graben walls occurred contemporaneously with primary sedimentation, as is conceivable from the winnowing and bottom-current activity suggested for this site, then there is no reason to suppose that the overall features of the $\delta^{13} \mathrm{C}$ decline would be lost. Clearly, the data at present are insufficient to distinguish the relative contributions to the $\delta^{13} \mathrm{C}$ decline of primary and secondary sedimentation across the Cretaceous/Tertiary boundary at Hole $807 \mathrm{C}$. As a check on the reproducibility of our data, we have repeated some measurements over the $\delta^{13} \mathrm{C}$ minimum as well as replicating five additional times selected measurements over the entire $\delta^{13} \mathrm{C}$ decline (Tables 2 and 3). Both types of repeat analyses show good agreement (Fig. 4) with our original measurements, confirming the expanded nature of this Cretaceous/Tertiary boundary $\delta^{13} \mathrm{C}$ decline at Hole $807 \mathrm{C}$.

Figure 3 shows that the initiation of the most rapid $\delta^{13} \mathrm{C}$ decline occurs at 1202.25 mbsf (Sample 130-807C-55R-4, 85-87 cm). This is significantly below the FO of Tertiary planktonic foraminifers, which occurs at $1197.32 \mathrm{mbsf}$ (Sample 130-807C-55R-1, 42-43 cm). The $\delta^{13} \mathrm{C}$ values continue to decline with minor fluctuations, reaching a minimum at 1193.02 mbsf (Sample 130-807C-54R-3, 122-124 cm). This is coincident with the peak in the Thoracosphaera bloom noted by the shipboard biostratigraphers (Shipboard Scientific Party, 1991) and initially used to locate the position of the Cretaceous/Tertiary boundary at Hole $807 \mathrm{C}$. The amplitude of the $\delta^{13} \mathrm{C}$ decline between 1202.25 and 1193.02 mbsf is $1.7 \%$. If secondary sedimentation was pervasive during the deposition of this boundary succession, then the stratigraphic separation of the onset of $\delta^{13} \mathrm{C}$ decline and the last occurrence (LO) of Cretaceous planktonic foraminifers and Cretaceous nannofossils could be caused by the reworking of these fossils higher up the section. However, the Cretaceous/Tertiary boundary has been placed on the FO of Danian planktonic foraminifers between Samples 130-807C-55R-1, 49-50 cm, and -55R-1,35-36 cm (1197.39 and 1197.25 mbsf; median $=1197.32$ ). It is difficult to explain the separation of the onset of $\delta^{13} \mathrm{C}$ decline and the first occurrence of Danian planktonic foraminifers by reworking. Hence, this separation must be considered a primary phenomenon in the absence of data to the contrary.

The $\delta^{18} \mathrm{O}$ data remain relatively constant over the interval between 1202.5 mbsf (Sample 130-807C-55R-4, $110 \mathrm{~cm}$ ) and $1196.97 \mathrm{mbsf}$
(Sample 130-807C-55R-1, 7-8 cm). After an interval of no recovery (placed by ODP convention at the base of the core barrel), $\delta^{18} \mathrm{O}$ values are about $0.1 \%$ more negative at $-1.8 \%$. At $1193.02 \mathrm{mbsf}$, coincident with the peak in the Thoracosphaera bloom, $\delta^{18} \mathrm{O}$ values begin to increase. The $\delta^{18} \mathrm{O}$ increase peaks at $1190.26 \mathrm{mbsf}$ (Sample 130$807 \mathrm{C}-54 \mathrm{R}-1,146-148 \mathrm{~cm}$ ) and its amplitude is $0.6 \%$. Recrystallization is widespread within this section, and it is impossible, therefore, to make specific assertions about absolute change in temperature. In particular, the $\delta^{18} \mathrm{O}$ values are relatively negative (in general, fluctuating around $-1.8 \%$ ) compared with other important Cretaceous/Tertiary boundary successions from the deep ocean. Whole-rock or fine-fraction measurements from DSDP Holes 47.2 and 577 (Zachos et al., 1985) fluctuate around approximately $-1 \%$, whereas fine-fraction measurements from a depth transect of Cretaceous/Tertiary boundary sites drilled during DSDP Leg 74 (Shackleton and Hall, 1984 ) are in the $0.0 \%$ to about $-0.5 \%$ range. As DSDP Hole 577 was in the tropics during the Late Cretaceous and Paleocene, these finefraction values may be considered to reflect sea-surface temperatures as monitored predominantly by nannofossils. Our more negative results from Hole $807 \mathrm{C}$ are therefore likely to be the result of recrystallization at relatively elevated deep burial temperatures. However, recrystallization in the absence of conspicuous quantities of organic matter is unlikely to have significantly modified the shape of the $\delta^{13} \mathrm{C}$ decline (e.g., Williams et al., 1988).

Our data show that the beginning of the $\delta^{13} \mathrm{C}$ decrease precedes the FO of Tertiary planktonic foraminifers, but that the apparent onset of the $\delta^{13} \mathrm{C}$ decline may be more or less synchronous with the beginning of the Cretaceous/Tertiary boundary interval as recognized using nannofossils (Mao and Wise, this volume). We note, however, that the position of the Cretaceous/Tertiary boundary is difficult to place precisely because of poor preservation and reworking.

If we assume that the apparent separation of the FO of Tertiary planktonic foraminifers and the onset of $\delta^{13} \mathrm{C}$ decline is a primary feature of the record at Hole $807 \mathrm{C}$, then it is useful to attempt to constrain the relative timing of events. We have developed a time scale for this interval of Hole $807 \mathrm{C}$ (Fig. 5), and our estimates suggest that the onset of the $\delta^{13} \mathrm{C}$ decline precedes the extinction by $450,000 \mathrm{yr}$. Note that this is certainly an overestimate due to the use of the $S$. pseudobulloides datum in a reworked succession. Other workers have shown that the $\delta^{13} \mathrm{C}$ decline preceded the extinction of the planktonic foraminifers (e.g., at neritic sites exposed in Europe [Perch-Nielson et al., 1982] and at DSDP 524 [Hsü et al., 1982]). Hence, it is not surprising that in the expanded section recovered at Hole $807 \mathrm{C}$ this feature should also be distinguished.

Macleod and Keller (1991) have recently pointed out that the apparent rapidity of the $\delta^{13} \mathrm{C}$ decline at the Cretaceous/Tertiary boundary in deep-sea sections may be a result of the widespread occurrence of hiatuses across the boundary interval. The implication, therefore, is that if the $\delta^{13} \mathrm{C}$ decline is gradual then the probability exists that the boundary is more complete than where the $\delta^{13} \mathrm{C}$ decline is abrupt. It is an unfortunate feature of the Cretaceous/Tertiary boundary section at Hole $807 \mathrm{C}$ that at present the nannofossil biostratigraphy is inadequate to accurately constrain the precise sequence of floral events with respect to the $\delta^{13} \mathrm{C}$ curve. Given the reservations of Mao and Wise (this volume) concerning the poor preservation and reworking of nannofossils across this Cretaceous/Tertiary boundary succession, it may well be that further refinement of the nannofossil biostratigraphy is not possible. It is clear, however, that the $\delta^{13} \mathrm{C}$ decline and the FO of Tertiary planktonic foraminifers occurs before the Thoracosphaera bloom. This is consistent with the hypothesis that the Thoracosphaera bloom was a response to vacated ecospace (the "Strangelove Ocean" of Hsü and McKenzie, 1985).

We conclude that the unique sedimentological setting of Hole $807 \mathrm{C}$ has led to the recovery of an apparently complete record of the $\delta^{13} \mathrm{C}$ change across the Cretaceous/Tertiary boundary event, although the succession contains a significant component from resedimentation. We note, however, that reworking was apparently 
pervasive at the relatively thick Cretaceous/Tertiary boundary section at DSDPSite 527 without markedly deforming the $\delta^{13} \mathrm{C}$ decline across the Cretaceous/Tertiary boundary there. However, those measurements were made on unlithified samples and were relatively unaffected by the problems of secondary cementation noted in Hole 807C.

\section{ACKNOWLEDGMENTS}

We are grateful to Isabella Premoli Silva and Bill Sliter for making available their planktonic foraminiferal biostratigraphy of the Cretaceous/Tertiary boundary interval in Hole $807 \mathrm{C}$. We thank John Tarduno for making available his paleomagnetic data for the Cretaceous/Tertiary interval in Hole $807 \mathrm{C}$. We are also grateful to Mike Durkin for valuable and stimulating discussion and for reading earlier versions of this manuscript. Finally, we are sincerely grateful to Lowell Stott and Jim Zachos for careful and constructive reviews of this paper, which substantially improved the final version.

\section{REFERENCES*}

Berggren, W.A., Kent, D.V. and Flynn, J.J., 1985. Jurassic to Paleogene: Part 2. Paleogene geochronology and chronostratigraphy. In Snelling, N.J. (Ed.), The Chronology of the Geological Record. Geol. Soc. London Mem., 10:141-195.

Berggren, W.A., and Miller, K.G., 1988. Paleogene tropical planktonic foraminiferal biostratigraphy and magnetobiochronology. Micropaleontology, 34:362-380.

Boersma, A., 1984. Cretaceous-Tertiary planktonic foraminifers from the southeastern Atlantic, Walvis Ridge area, Deep Sea Drilling Project Leg 74. In Moore, T.C., Jr., Rabinowitz, P.D., et al., Init. Repts. DSDP, 74: Washington (U.S. Govt. Printing Office), 501-524.

Corfield, R.M., Cartlidge, J.E., Premoli Silva, I., and Housley, R.A., 1991. Oxygen and carbon isotope stratigraphy of the Paleogene and Cretaceous limestones in the Bottaccione Gorge and the Contessa Highway sections, Umbria, Italy. Terra Nova, 3:414-422.

Corfield, R.M., and Shackleton, N.J., 1988. Comment and reply on "Danian faunal succession: planktonic foraminiferal response to a changing marine environment." Geology, 16:378-379.

Gerstel, J., Thunell, R.C., Zachos, J.C., and Arthur, M.A., 1986. The Cretaceous/Tertiary boundary events in the North Pacific: planktonic foraminiferal results from Deep Sea Drilling Project Site 577, Shatsky Rise. Paleoceanography, 1:97-117.

Hsü, K.J., He, Q., McKenzie, J.A., Weissert, H., Perch-Nielson, K., Oberhänsli, H., Kelts, K., LaBrecque, J., Tauxe, L., Krähenbühl, U., Percival, S.F., Wright, R., Karpoff, A.M., Petersen, N., Tucker, P., Poore, R.Z., Gombos, A.M., Pisciotto, K., Carman, M.F., Schreiber, E., 1982. Mass mortality and its environmental and evolutionary consequences. Science, 216:249-256.

Hsü, K.J., and McKenzie, J.A., 1985. A "strangelove" ocean in the earliest Tertiary. In Sundquist, E.T., and Broecker, W.S. (Eds.), The Carbon Cycle and Atmospheric $\mathrm{CO}_{2}$ : Natural Variations Archean to Present. Am. Geophys. Union, Geophys. Monogr., 32:487-492.

Macleod, N., and Keller, G., 1991. Hiatus distributions and mass extinctions at the Cretaceous/Tertiary boundary. Geology, 19:497-501.

Perch-Nielson, K., McKenzie, J., and He, Q., 1982. Biostratigraphy and isotope stratigraphy and the "catastrophic" extinction of calcareous nannoplankton at the Cretaceous/Tertiary boundary. In Silver, L.T., and
Schultz, P.H. (Eds.), Geological Implications of Impacts of Large Asteroids and Comets on the Earth. Spec. Pap., Geol. Soc. Am., 190:353-371.

Pospichal, J.J., and Wise, S.W., Jr., 1990. Calcareous nannofossils across the $\mathrm{K} / \mathrm{T}$ boundary, ODP Hole $690 \mathrm{C}$, Maud Rise, Weddell Sea. In Barker, P.F., Kennett, J.P., et al., Proc. ODP, Init. Repts., 113: College Station, TX (Ocean Drilling Program), 515-532.

Renard, M., 1986. Pelagic carbonate chemostratigraphy $\left(\mathrm{Sr}, \mathrm{Mg},{ }^{18} \mathrm{O},{ }^{13} \mathrm{C}\right)$, Mar. Micropaleontol., 10:117-164.

Savin, S.M., 1977. The history of the Earth's surface temperature during the past 100 million years. Annu. Rev. Earth. Planet. Sci., 5:319-355.

Scholle, P.A., and Arthur, M.A., 1980. Carbon isotope fluctuations in Cretaceous pelagic limestones: potential stratigraphic and petroleum exploration tool. AAPG Bull., 64:67-87

Shackleton, N.J., and Hall, M.A., 1984. Carbon isotope data from Leg 74 sediments. In Moore, T.C., Jr., Rabinowitz, P.D., et al., Init. Repts. DSDP, 74: Washington (U.S. Govt. Printing Office), 613-619.

Shackleton, N.J., Hall, M.A., and Bleil, U., 1985. Carbon isotope stratigraphy, Site 577. In Heath, G.R., Burckle, L.H., et al., Init. Repts. DSDP, 86: Washington (U.S. Govt. Printing Office), 503-512.

Shipboard Scientific Party, 1991. Site 807. In Kroenke, L.W., Berger, W.H., Janecek, T.R., et al., Proc. ODP, Init. Repts., 130: College Station, TX (Ocean Drilling Program), 369-493.

Stott, L.D., and Kennett, J.P., 1990. The paleoceanographic and paleoclimatic signature of the Cretaceous/Paleogene boundary in the Antarctic: stable isotopic results from ODP Leg 113. In Barker, P.F., Kennett, J.P., et al., Proc. ODP, Init. Repts., 113: College Station, TX (Ocean Drilling Program), 829-848.

Stott, L.D., Kennett, J.P., Shackleton, N.J., and Corfield, R.M., 1990. The evolution of Antarctic surface waters during the Paleogene: inferences from stable isotopic composition of planktonic foraminifers, ODP Leg 113. Proc. ODP, Sci. Results, 113: College Station, TX (Ocean Drilling Program), 849-863.

Thomas, E., Barrera, E., Hamilton, N., Huber, B.T., Kennett, J.P., O'Connell, S.B., Pospichal, J.J., SpieB, V., Stott, L.D., Wei, W., and Wise, S.W., Jr., 1990. Upper Cretaceous-Paleogene stratigraphy of Sites 689 and 690 , Maud Rise, (Antarctica). In Barker, P.F., Kennett, J.P., et al., Proc. ODP, Sci. Results, 113: College Station, TX (Ocean Drilling Program), 901-914.

Williams, D.F., Lerche, I., and Full, W.E., 1988. Isotope Chronostratigraphy; San Diego (Academic Press).

Zachos, J.C., and Arthur, M.A., 1986. Paleoceanography of the Cretaceous/Tertiary boundary event: inferences from stable isotopic and other data. Paleoceanography, 1:5-26.

Zachos, J.C., Arthur, M.A., Thunell, R.C., Williams, D.F., and Tappa, E.J., 1985. Stable isotope and trace element geochemistry of carbonate sediments across the Cretaceous/Tertiary boundary at Deep Sea Drilling Project Hole 577, Leg 86. In Heath, G.R., Burckle, L.H., et al., Init. Repts. DSDP, 86: Washington (U.S. Govt. Printing Office), 513-532.

* Abbreviations for names of organizations and publication titles in ODP reference lists follow the style given in Chemical Abstracts Service Source Index (published by American Chemical Society).

Date of initial receipt: 9 September 1991

Date of acceptance: 1 September 1992

Ms 130B-027 


\begin{tabular}{|c|c|c|c|c|}
\hline யே & 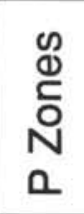 & & 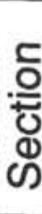 & 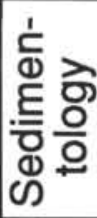 \\
\hline \multirow{4}{*}{ 疍 } & P3a? & \multirow{4}{*}{ 寽 } & 1 & Turbidite \\
\hline & & & 2 & \multirow{3}{*}{ 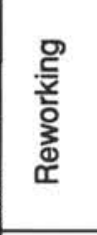 } \\
\hline & ra & & 3 & \\
\hline & $\mathrm{Pa}$ & & & \\
\hline \multirow{5}{*}{ 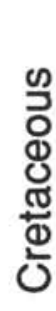 } & & & 1 & \multirow{5}{*}{ 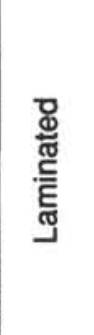 } \\
\hline & & & 2 & \\
\hline & & 范 & 3 & \\
\hline & & เึ่ & 4 & \\
\hline & & & & \\
\hline
\end{tabular}
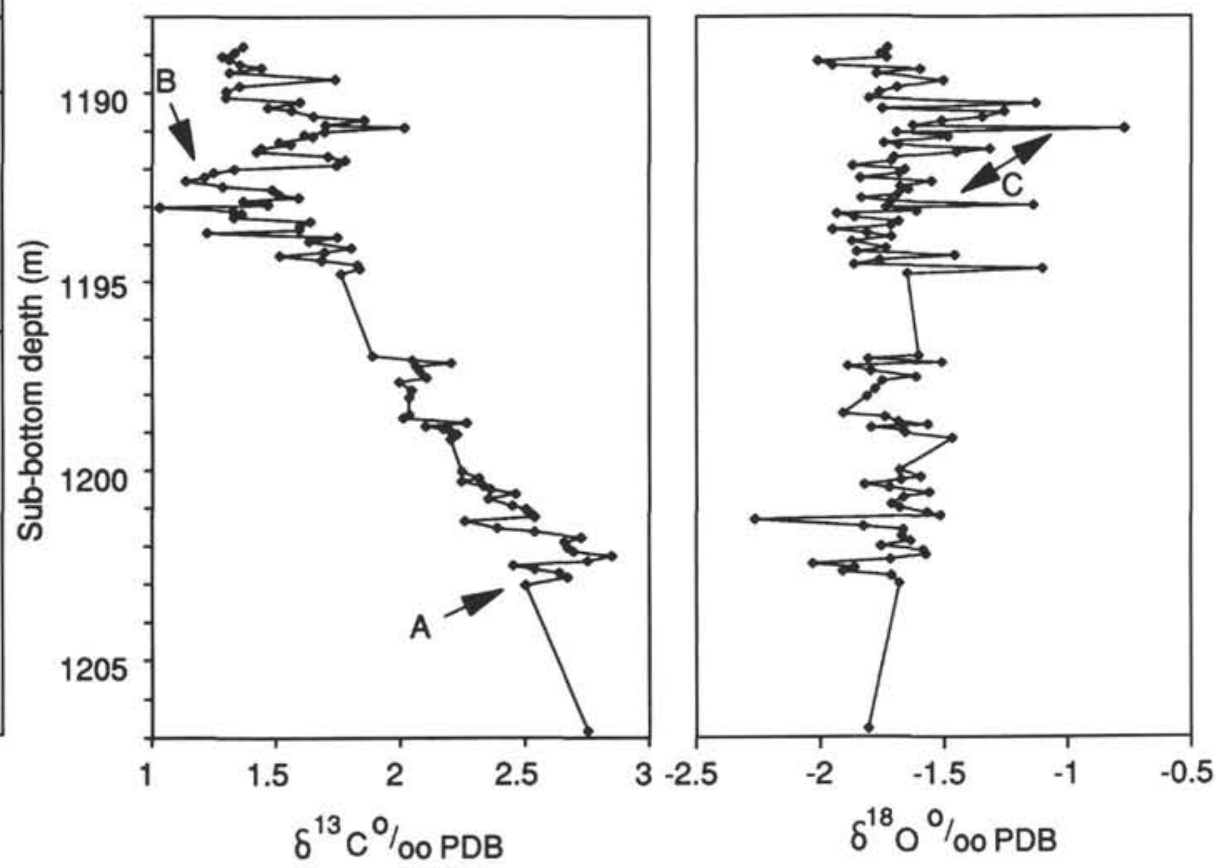

Figure 3. Oxygen and carbon isotope stratigraphy of the Cretaceous/Tertiary transition at Hole $807 \mathrm{C}$ with foraminiferal zones and sedimentology of Premoli Silva (this volume).

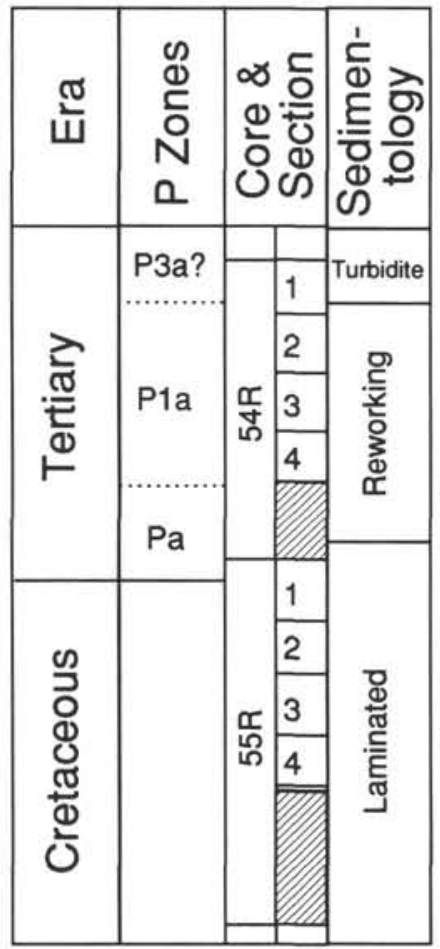
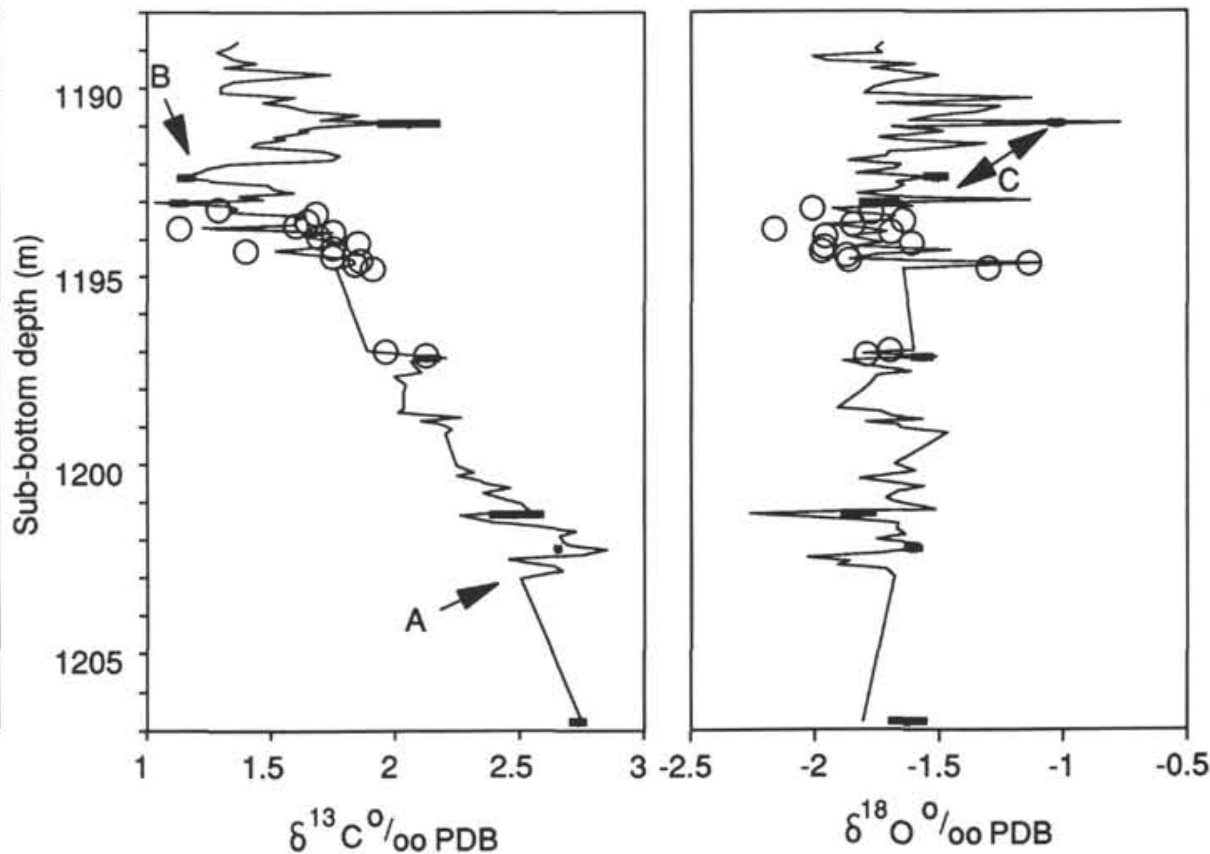

Figure 4. Repeat analyses of whole-rock carbonates across the Cretaceous/Tertiary boundary succession at Hole $807 \mathrm{C}$. Circles refer to individually repeated measurements, solid bars are 1 standard deviation around the mean of 5 additional measurements of that sample. 
Table 2. Repeated single measurements on selected carbonates across the $\delta^{13} \mathrm{C}$ minimum of the Cretaceous/Tertiary boundary at Hole 807C.

\begin{tabular}{|c|c|c|c|c|c|}
\hline Lab no. & $\begin{array}{l}\text { Hole, core, section, } \\
\text { interval }(\mathrm{cm})\end{array}$ & $\begin{array}{l}\text { Depth } \\
\text { (mbsf) }\end{array}$ & $\delta^{13} \mathrm{C}$ & $\delta^{18} \mathrm{O}$ & $\begin{array}{l}\text { Age } \\
\text { (Ma) }\end{array}$ \\
\hline A90/2016 & $807 \mathrm{C}-54 \mathrm{R}-3,139$ & 1193.19 & 1.28 & -2.00 & 66.07 \\
\hline A90/2017 & $807 \mathrm{C}-54 \mathrm{R}-3,149$ & 1193.29 & 1.68 & -1.77 & 66.08 \\
\hline A90/2019 & $807 \mathrm{C}-54 \mathrm{R}-4,20$ & 1193.50 & 1.64 & -1.64 & 66.10 \\
\hline A90/2020 & $807 \mathrm{C}-54 \mathrm{R}-4,31$ & 1193.61 & 1.60 & -1.84 & 66.11 \\
\hline A90/2021 & $807 \mathrm{C}-54 \mathrm{R}-4,40$ & 1193.70 & 1.13 & -2.15 & 66.11 \\
\hline A90/2022 & $807 \mathrm{C}-54 \mathrm{R}-4,50$ & 1193.80 & 1.75 & -1.69 & 66.12 \\
\hline A90/2023 & $807 C-54 R-4,62$ & 1193.92 & 1.69 & -1.95 & 66.13 \\
\hline A90/2024 & $807 C-54 R-4,80$ & 1194.10 & 1.85 & -1.61 & 66.15 \\
\hline A90/2025 & $807 C-54 R-4,90$ & 1194.20 & 1.74 & -1.96 & 66.15 \\
\hline A90/2026 & $807 \mathrm{C}-54 \mathrm{R}-4,100$ & 1194.30 & 1.39 & -1.97 & 66.16 \\
\hline A90/2027 & $807 C-54 R-4,113$ & 1194.43 & 1.75 & -1.87 & 66.17 \\
\hline A90/2028 & $807 \mathrm{C}-54 \mathrm{R}-4,125$ & 1194.55 & 1.86 & -1.86 & 66.18 \\
\hline A90/2029 & $807 C-54 R-4,135$ & 1194.65 & 1.83 & -1.14 & 66.19 \\
\hline A90/2030 & $807 C-54 R-4,148$ & 1194.78 & 1.91 & -1.30 & 66.20 \\
\hline A90/2031 & $807 C-55 R-1,7$ & 1196.97 & 1.96 & -1.69 & 66.37 \\
\hline A90/2032 & $807 \mathrm{C}-55 \mathrm{R}-1,17$ & 1197.07 & 2.12 & -1.78 & 66.38 \\
\hline
\end{tabular}

Table 3. Multiple replicates of selected carbonates across the Cretaceous/Tertiary boundary succession at Hole $807 \mathrm{C}$.

\begin{tabular}{|c|c|c|c|c|c|c|c|c|}
\hline Lab no. & $\begin{array}{l}\text { Hole, core, section, } \\
\text { interval }(\mathrm{cm})\end{array}$ & $\begin{array}{l}\text { Depth } \\
\text { (mbsf) }\end{array}$ & $\delta^{13} \mathrm{C}$ & $\delta^{18} \mathrm{O}$ & $\begin{array}{l}\text { Mean } \\
\delta^{13} \mathrm{C}\end{array}$ & $\begin{array}{c}\text { Mean } \\
\delta^{18} \mathrm{O}\end{array}$ & $\begin{array}{c}1 \sigma \\
\delta^{13} \mathrm{C}\end{array}$ & $\begin{array}{c}1 \sigma \\
\delta^{18} \mathrm{O}\end{array}$ \\
\hline $\mathrm{NOCZ}$ & $807 \mathrm{C}(5 / 8 / 92)$ & - & 2.24 & -1.96 & 2.27 & -1.90 & 0.02 & 0.07 \\
\hline NOCZ & $807 \mathrm{C}(5 / 8 / 92)$ & - & 2.26 & -1.93 & - & - & - & - \\
\hline NOCZ & $807 \mathrm{C}(5 / 8 / 92)$ & - & 2.29 & -1.80 & - & - & - & - \\
\hline NOCZ & $807 \mathrm{C}(5 / 8 / 92)$ & - & 2.28 & -1.90 & - & - & - & - \\
\hline A92/2244 & $807 C-54 R-2,62$ & 1190.92 & 2.30 & -0.95 & 2.06 & -0.99 & 0.14 & 0.04 \\
\hline A92/2245 & $807 C-54 R-2,62$ & 1190.92 & 2.03 & -0.96 & - & - & - & - \\
\hline A92/2246 & $807 C-54 R-2,62$ & 1190.92 & 1.98 & -1.04 & - & - & - & - \\
\hline A92/2247 & $807 C-54 R-2,62$ & 1190.92 & 1.98 & -1.01 & - & - & - & - \\
\hline A9 $2 / 2248$ & $807 C-54 R-2,62$ & 1190.92 & 2.00 & -1.00 & - & - & - & - \\
\hline A92/2249 & $807 \mathrm{C}-54 \mathrm{R}-3,53$ & 1192.33 & 1.07 & -1.59 & 1.08 & -1.52 & 0.04 & 0.05 \\
\hline A92/2250 & $807 \mathrm{C}-54 \mathrm{R}-3,53$ & 1192.33 & 1.15 & -1.54 & - & - & - & - \\
\hline A92/2251 & $807 \mathrm{C}-54 \mathrm{R}-3,53$ & 1192.33 & 1.08 & -1.45 & - & - & - & - \\
\hline A92/2252 & $807 \mathrm{C}-54 \mathrm{R}-3,53$ & 1192.33 & 1.05 & -1.52 & - & - & - & - \\
\hline A92/2253 & $807 \mathrm{C}-54 \mathrm{R}-3,53$ & 1192.33 & 1.08 & -1.49 & - & - & - & - \\
\hline A92/2254 & $807 \mathrm{C}-54 \mathrm{R}-3,122$ & 1193.02 & 1.00 & -1.81 & 1.05 & -1.76 & 0.04 & 0.09 \\
\hline A92/2255 & $807 \mathrm{C}-54 \mathrm{R}-3,122$ & 1193.02 & 1.10 & -1.70 & - & - & - & - \\
\hline A92/2256 & $807 \mathrm{C}-54 \mathrm{R}-3,122$ & 1193.02 & 1.09 & -1.79 & - & 一 & - & - \\
\hline A92/2257 & $807 \mathrm{C}-54 \mathrm{R}-3,122$ & 1193.02 & 1.04 & -1.65 & - & - & - & - \\
\hline A92/2258 & $807 \mathrm{C}-54 \mathrm{R}-3,122$ & 1193.02 & 1.04 & -1.86 & - & - & - & - \\
\hline A92/2259 & $807 \mathrm{C}-55 \mathrm{R}-1,26$ & 1197.16 & 2.07 & -1.63 & 2.15 & -1.57 & 0.05 & 0.05 \\
\hline A $92 / 2260$ & $807 \mathrm{C}-55 \mathrm{R}-1,26$ & 1197.16 & 2.16 & -1.55 & - & - & - & - \\
\hline A92/2261 & $807 \mathrm{C}-55 \mathrm{R}-1,26$ & 1197.16 & 2.20 & -1.56 & - & - & - & - \\
\hline A92/2262 & $807 C-55 R-1,26$ & 1197.16 & 2.11 & -1.62 & - & - & - & - \\
\hline A92/2263 & $807 \mathrm{C}-55 \mathrm{R}-1,26$ & 1197.16 & 2.18 & -1.52 & - & - & - & - \\
\hline A92/2264 & $807 \mathrm{C}-55 \mathrm{R}-3,143$ & 1201.33 & 2.39 & -1.94 & 2.53 & -1.85 & 0.12 & 0.08 \\
\hline A92/2265 & $807 C-55 R-3,143$ & 1201.33 & 2.71 & -1.78 & - & - & - & - \\
\hline A92/2266 & $807 C-55 R-3,143$ & 1201.33 & 2.48 & -1.92 & - & - & - & - \\
\hline A $92 / 2267$ & $807 C-55 R-3,143$ & 1201.33 & 2.56 & -1.84 & - & - & - & - \\
\hline A92/2268 & $807 C-55 \mathrm{R}-3,143$ & 1201.33 & 2.50 & -1.79 & - & - & - & - \\
\hline A92/2269 & $807 C-55 R-4,85$ & 1202.25 & 2.69 & -1.60 & 2.71 & -1.62 & 0.02 & 0.04 \\
\hline A $92 / 2270$ & $807 \mathrm{C}-55 \mathrm{R}-4,85$ & 1202.25 & 2.69 & -1.63 & - & - & - & - \\
\hline A $92 / 2271$ & $807 \mathrm{C}-55 \mathrm{R}-4,85$ & 1202.25 & 2.72 & -1.58 & - & - & - & - \\
\hline A $92 / 2272$ & $807 \mathrm{C}-55 \mathrm{R}-4,85$ & 1202.25 & 2.72 & -1.68 & - & - & - & - \\
\hline A $92 / 2273$ & $807 C-55 \mathrm{R}-4,85$ & 1202.25 & 2.72 & -1.59 & - & - & - & - \\
\hline A92/2274 & $807 \mathrm{C}-56 \mathrm{R}-1,20$ & 1206.80 & 2.81 & -1.61 & 2.80 & -1.64 & 0.04 & 0.08 \\
\hline A $92 / 2275$ & $807 \mathrm{C}-56 \mathrm{R}-1,20$ & 1206.80 & 2.84 & -1.55 & - & - & - & - \\
\hline A92/2276 & $807 \mathrm{C}-56 \mathrm{R}-1,20$ & 1206.80 & 2.74 & -1.77 & - & - & - & - \\
\hline A92/2277 & $807 \mathrm{C}-56 \mathrm{R}-1,20$ & 1206.80 & 2.78 & -1.60 & - & - & - & - \\
\hline A92/2278 & $807 \mathrm{C}-56 \mathrm{R}-1,20$ & 1206.80 & 2.81 & -1.67 & - & - & - & - \\
\hline $\mathrm{NOCZ}$ & $807 \mathrm{C}(5 / 8 / 92)$ & - & 2.32 & -1.89 & 2.31 & -1.85 & 0.01 & 0.05 \\
\hline NOCZ & $807 \mathrm{C}(5 / 8 / 92)$ & - & 2.30 & -1.91 & - & - & - & - \\
\hline $\mathrm{NOCZ}$ & $807 \mathrm{C}(5 / 8 / 92)$ & - & 2.33 & -1.80 & - & - & - & - \\
\hline $\mathrm{NOCZ}$ & $807 \mathrm{C}(5 / 8 / 92)$ & - & 2.31 & -1.83 & - & - & - & - \\
\hline $\mathrm{NOCZ}$ & $807 \mathrm{C}(5 / 8 / 92)$ & - & 2.30 & -1.81 & - & - & - & - \\
\hline
\end{tabular}

Notes: NOCZ refers to the Oxford in-house marble standard and is included to illustrate that reproducibility of Hole $807 \mathrm{C}$ whole-rock carbonate samples was similar to the reproducibility of our calibrating standard. 


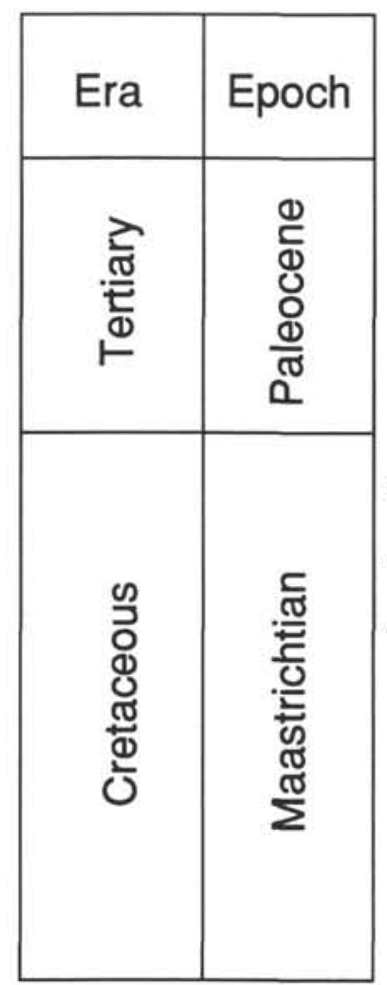
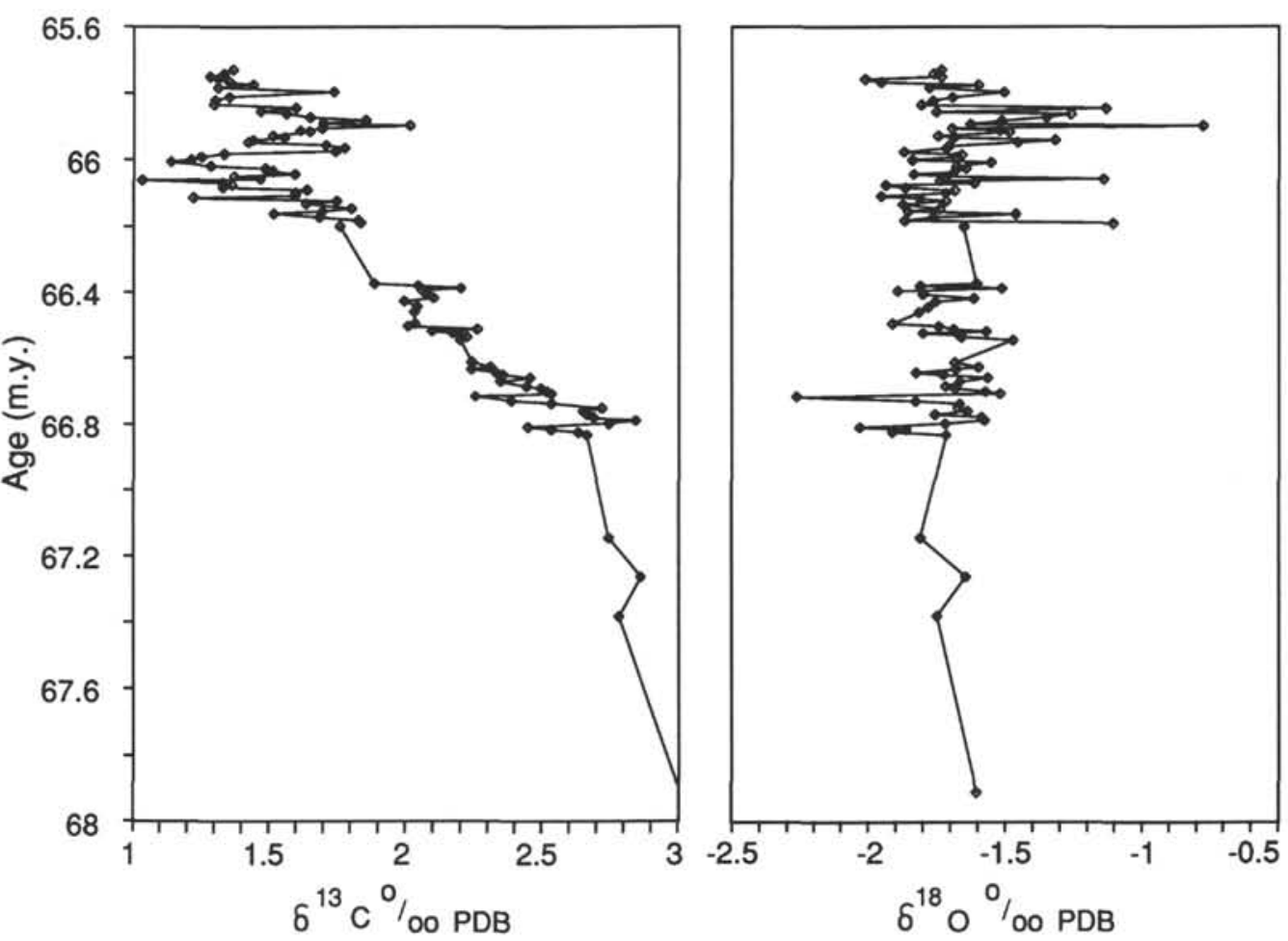

Figure 5. Oxygen and carbon isotope chronostratigraphy of the Cretaceous/Tertiary transition at Hole $807 \mathrm{C}$. Note that the $\delta^{13} \mathrm{C}$ starts at $66.85 \mathrm{Ma}$ using our age estimates, and this decline precedes the first occurrence of Tertiary planktonic foraminifers (at $66.4 \mathrm{Ma}$ ) by 450,000 yr. Also note uncertainties in our time scale caused by the use of a foraminiferal datum ( $S$. pseudobulloides) in a reworked succession. 
APPENDIX

Oxygen and carbon isotope data from Holes 807A and 807C

\begin{tabular}{|c|c|c|c|c|c|c|c|c|c|c|c|}
\hline Lab no. & $\begin{array}{l}\text { Hole, core, section, } \\
\text { interval }(\mathrm{cm})\end{array}$ & $\delta^{13} \mathrm{C}$ & $\delta^{18} \mathrm{O}$ & $\begin{array}{l}\text { Depth } \\
\text { (mbsf) }\end{array}$ & $\begin{array}{l}\text { Age } \\
(\mathrm{Ma})\end{array}$ & Lab no. & $\begin{array}{l}\text { Hole, core, section, } \\
\text { interval }(\mathrm{cm})\end{array}$ & $\delta^{13} \mathrm{C}$ & $\delta^{18} \mathrm{O}$ & $\begin{array}{l}\text { Depth } \\
\text { (mbsf) }\end{array}$ & $\begin{array}{l}\text { Age } \\
(\mathrm{Ma})\end{array}$ \\
\hline A90/2674 & $807 \mathrm{~A}-68 \mathrm{X}-1,138$ & 1.31 & -0.09 & 641.28 & - & A90/2773 & $807 C-4 R-2,73$ & 1.59 & -0.24 & 811.23 & - \\
\hline A $90 / 2675$ & 807 A- $68 X-2,78$ & 1.38 & -0.17 & 642.18 & - & A90/2774 & $807 A-86 X-1,60$ & 1.84 & -0.02 & 813.80 & - \\
\hline A90/2676 & $807 \mathrm{~A}-68 \mathrm{X}-3,61$ & 1.31 & -0.10 & 643.51 & - & A90/2878 & $807 A-86-2,60$ & 1.76 & 0.03 & 815.30 & - \\
\hline A90/2678 & $807 \mathrm{~A}-68 \mathrm{X}-5,37$ & 1.06 & -0.18 & 646.27 & - & A90/2775 & $807 \mathrm{C}-6 \mathrm{R}-1,73$ & 1.60 & -0.12 & 829.03 & - \\
\hline A90/2679 & $807 \mathrm{~A}-69 \mathrm{X}-1,75$ & 1.18 & -0.07 & 650.35 & - & A90/2776 & $807 C-6 R-2,73$ & 1.55 & -0.15 & 830.53 & - \\
\hline A $90 / 2680$ & $807 \mathrm{~A}-70 \mathrm{X}-1,10$ & 1.41 & -0.56 & 659.30 & - & A90/2777 & $807 C-6 R-3,73$ & 1.54 & -0.10 & 832.03 & - \\
\hline A90/2681 & $807 \mathrm{~A}-70 \mathrm{X}-2,10$ & 1.38 & -0.17 & 660.80 & - & A90/2778 & $807 C-6 R-4,73$ & 1.66 & 0.04 & 833.53 & - \\
\hline A90/2682 & $807 \mathrm{~A}-70 \mathrm{X}-3,10$ & 1.51 & -0.15 & 662.30 & - & A90/2779 & $807 C-6 R-5,73$ & 1.74 & -0.08 & 835.03 & - \\
\hline A $90 / 2683$ & $807 \mathrm{~A}-70 \mathrm{X}-4,10$ & 1.30 & -0.24 & 663.80 & - & A $90 / 2780$ & $807 C-12 R-1,35$ & 1.76 & -0.10 & 876.95 & - \\
\hline A90/2684 & $807 \mathrm{~A}-70 \mathrm{X}-5,10$ & 1.67 & -0.04 & 665.30 & - & $\mathrm{A} 90 / 2781$ & $807 \mathrm{C}-15 \mathrm{R}-1,57$ & 1.99 & -0.66 & 894.47 & - \\
\hline A90/2686 & $807 \mathrm{~A}-70 \mathrm{X}-\mathrm{CC}, 10$ & 1.44 & 0.07 & 667.36 & - & A90/2782 & $807 \mathrm{C}-16 \mathrm{R}-1,78$ & 1.92 & -0.80 & 899.68 & - \\
\hline A90/2687 & $807 \mathrm{~A}-71 \mathrm{X}-1,45$ & 1.64 & 0.08 & 669.35 & - & A90/2783 & $807 \mathrm{C}-17 \mathrm{R}-1,76$ & 1.55 & -0.73 & 904.66 & - \\
\hline A90/2688 & $807 \mathrm{~A}-71 \mathrm{X}-2,45$ & 1.47 & -0.13 & 670.85 & - & A90/2784 & $807 \mathrm{C}-17 \mathrm{R}-2,73$ & 1.56 & -0.62 & 906.13 & - \\
\hline $\mathrm{A} 90 / 2689$ & $807 \mathrm{~A}-71 \mathrm{X}-3,45$ & 2.17 & 0.19 & 672.35 & - & A90/2785 & $807 \mathrm{C}-18 \mathrm{R}-\mathrm{CC}, 2$ & 1.63 & -0.71 & 908.92 & 一 \\
\hline $\mathrm{A} 90 / 2690$ & $807 A-71 X-4,45$ & 2.13 & 0.20 & 673.85 & - & A90/2786 & $807 \mathrm{C}-19 \mathrm{R}-1,55$ & 1.75 & -0.74 & 914.45 & - \\
\hline A90/2692 & 807A-71X-CC, 45 & 1.92 & 0.05 & 676.85 & - & A $90 / 2787$ & $807 \mathrm{C}-20 \mathrm{R}-1,1$ & 1.86 & -0.80 & 918.91 & - \\
\hline A90/2693 & $807 A-72 X-1,42$ & 1.66 & 0.05 & 678.62 & - & A90/2788 & $807 \mathrm{C}-21 \mathrm{R}-1,12$ & 2.07 & -0.67 & 924.02 & - \\
\hline A90/2694 & $807 \mathrm{~A}-72 \mathrm{X}-2,42$ & 2.00 & 0.28 & 680.12 & - & A90/2789 & $807 \mathrm{C}-22 \mathrm{R}-1,12$ & 1.98 & -0.99 & 933.82 & - \\
\hline A90/2695 & $807 \mathrm{~A}-72 \mathrm{X}-3,42$ & 2.01 & 0.09 & 681.62 & - & A90/2790 & $807 C-23 R-1,64$ & 2.06 & -0.96 & 939.34 & - \\
\hline A90/2696 & $807 \mathrm{~A}-72 \mathrm{X}-4,42$ & 1.73 & 0.01 & 683.12 & - & A90/2791 & $807 C-23 R-2,64$ & 2.11 & -0.80 & 940.84 & - \\
\hline A90/2697 & $807 \mathrm{~A}-73 \mathrm{X}-1,70$ & 1.52 & 0.01 & 688.50 & - & A90/2792 & $807 C-23 R-3,64$ & 2.26 & -0.76 & 942.34 & - \\
\hline A90/2699 & $807 \mathrm{~A}-73 \mathrm{X}-2,70$ & 1.87 & -0.49 & 690.00 & - & A $90 / 2793$ & $807 C-23 R-4,16$ & 2.22 & -0.91 & 943.36 & - \\
\hline A90/2713 & $807 \mathrm{~A}-73 \mathrm{X}-3,70$ & 1.37 & 0.12 & 691.50 & - & A $90 / 2794$ & $807 \mathrm{C}-24 \mathrm{R}-1,73$ & 2.29 & -0.67 & 944.43 & - \\
\hline A90/2714 & $807 \mathrm{~A}-73 \mathrm{X}-4,70$ & 1.28 & -0.01 & 693.00 & - & $\mathrm{A} 90 / 2795$ & $807 \mathrm{C}-24 \mathrm{R}-2,74$ & 2.13 & -0.61 & 945.94 & - \\
\hline A90/2715 & $807 A-73 X-5,72$ & 1.47 & 0.16 & 694.52 & - & A90/2796 & $807 \mathrm{C}-25 \mathrm{R}-1,70$ & 2.22 & -0.83 & 949.10 & - \\
\hline A90/2716 & $807 A-73 X-6,70$ & 1.66 & -0.08 & 696.00 & - & A90/2797 & $807 \mathrm{C}-26 \mathrm{R}-1,73$ & 2.52 & -0.52 & 958.83 & - \\
\hline A90/2717 & 807 A- 74 X-1, 92 & 1.33 & -0.05 & 698.42 & - & A90/2798 & $807 \mathrm{C}-29 \mathrm{R}-1,16$ & 2.13 & -0.49 & 987.26 & - \\
\hline A90/2718 & $807 \mathrm{~A}-74 \mathrm{X}-2,92$ & 1.52 & -0.02 & 699.92 & - & A90/2866 & $807 \mathrm{C}-30 \mathrm{R}-2,27$ & 1.98 & -0.64 & 997.83 & - \\
\hline A90/2719 & $807 \mathrm{~A}-74 \mathrm{X}-3,92$ & 1.62 & 0.10 & 701.42 & - & A90/2867 & $807 \mathrm{C}-31 \mathrm{R}-1,8$ & 2.13 & -0.73 & 1006.58 & - \\
\hline A $90 / 2720$ & $807 \mathrm{~A}-75 \mathrm{X}-1,60$ & 1.75 & -0.01 & 707.80 & - & A90/2868 & $807 \mathrm{C}-32 \mathrm{R}-1,16$ & 2.63 & -1.02 & 1016.26 & - \\
\hline A90/2721 & $807 \mathrm{~A}-75 \mathrm{X}-2,60$ & 1.95 & 0.10 & 709.30 & - & A90/2869 & $807 C-33 R-1,2$ & 2.20 & -1.22 & 1025,42 & - \\
\hline A90/2722 & $807 \mathrm{~A}-75 \mathrm{X}-3,60$ & 1.71 & 0.07 & 710.80 & - & $\mathrm{A} 90 / 2870$ & $807 C-34 R-1,3$ & 2.37 & -1.15 & 1034.63 & - \\
\hline A90/2723 & $807 A-75 X-4,60$ & 1.33 & -0.07 & 712.30 & - & A90/2871 & $807 \mathrm{C}-35 \mathrm{R}-1,34$ & 1.95 & -0.92 & 1044.64 & - \\
\hline A90/2724 & $807 A-75 X-5,60$ & 1.40 & -0.06 & 713.80 & - & A $90 / 2872$ & $807 \mathrm{C}-37 \mathrm{R}-1,7$ & 1.91 & -0.97 & 1063.77 & - \\
\hline A90/2725 & $807 A-76 X-1,70$ & 1.38 & -0.12 & 717.60 & - & A90/2873 & $807 \mathrm{C}-38 \mathrm{R}-1,4$ & 2.12 & -1.11 & 1073.64 & - \\
\hline A90/2726 & 807 A- $76 \mathrm{X}-2,70$ & 1.53 & -0.16 & 719.10 & - & A90/2874 & $807 \mathrm{C}-39 \mathrm{R}-1,25$ & 2.08 & -1.03 & 1082.65 & - \\
\hline A $90 / 2727$ & 807 A-76X-3, 70 & 1.77 & 0.07 & 720.60 & - & A90/2875 & $807 \mathrm{C}-40 \mathrm{R}-1,45$ & 1.69 & -1.13 & 1092.45 & - \\
\hline A90/2728 & $807 A-76 X-4,70$ & 1.66 & 0.08 & 722.10 & - & A90/2876 & $807 C-41 R-1,32$ & 1.90 & -1.25 & 1098.02 & - \\
\hline A90/2729 & $807 A-76 X-5,70$ & 1.57 & -0.09 & 723.60 & - & A90/2877 & $807 \mathrm{C}-42 \mathrm{R}-1,74$ & 1.99 & -1.23 & 1103.14 & - \\
\hline A $90 / 2730$ & $807 A-76 X-6,50$ & 1.57 & 0.01 & 724.90 & - & A90/2811 & $807 C-43 R-1,71$ & 1.72 & -1.77 & 1107.11 & - \\
\hline A90/2731 & $807 A-77 X-1,56$ & 1.27 & -0.08 & 727.06 & - & A $90 / 2812$ & $807 C-44 R-1,76$ & 1.81 & -1.36 & 1116.76 & - \\
\hline A90/2732 & $807 A-77 X-2,56$ & 1.14 & -0.15 & 728.56 & - & A90/2813 & $807 C-45 R-1,65$ & 2.47 & -1.58 & 1126.25 & - \\
\hline A90/2734 & 807A-77X-3, 56 & 1.45 & -0.17 & 730.06 & - & A90/2814 & $807 C-45 R-2,64$ & 1.27 & -1.39 & 1127.74 & - \\
\hline A90/2736 & $807 \mathrm{~A}-77 \mathrm{X}-4,56$ & 1.51 & 0.33 & 731.56 & - & A90/2815 & $807 \mathrm{C}-46 \mathrm{R}-1,73$ & 1.50 & -1.39 & 1135.93 & - \\
\hline A $90 / 2743$ & $807 A-77 X-5,56$ & 1.45 & -0.05 & 733.06 & - & A90/2816 & $807 \mathrm{C}-46 \mathrm{R}-2,74$ & 1.44 & -1.31 & 1137.44 & - \\
\hline A $90 / 2745$ & $807 A-77 X-6,30$ & 1.43 & -0.03 & 734.30 & - & A90/2817 & $807 C-46 R-3,62$ & 1.24 & -0.89 & 1138.82 & - \\
\hline A90/2746 & $807 \mathrm{~A}-78 \mathrm{X}-1,56$ & 1.74 & 0.57 & 736.76 & - & A90/2818 & $807 \mathrm{C}-47 \mathrm{R}-1,70$ & 1.49 & -1.97 & 1140.90 & - \\
\hline A90/2747 & $807 A-78 X-2,56$ & 1.52 & 0.09 & 738.26 & - & A90/2819 & $807 \mathrm{C}-47 \mathrm{R}-2,88$ & 1.74 & -1.96 & 1142.58 & - \\
\hline A90/2748 & $807 \mathrm{~A}-78 \mathrm{X}-3,56$ & 1.81 & -0.04 & 739.76 & - & A90/2820 & $807 \mathrm{C}-48 \mathrm{R}-1,20$ & 1.83 & -1.99 & 1145.40 & - \\
\hline A90/2749 & $807 A-78 X-4,56$ & 1.79 & 0.36 & 741.26 & - & A90/2821 & $807 \mathrm{C}-48 \mathrm{R}-2,19$ & 2.33 & -1.93 & 1146.89 & - \\
\hline A90/2750 & $807 A-78 X-5,56$ & 1.57 & 0.07 & 742.76 & - & A90/2822 & $807 \mathrm{C}-49 \mathrm{R}-1,22$ & 2.06 & -2.10 & 1150.42 & - \\
\hline A90/2751 & $807 \mathrm{~A}-79 \mathrm{X}-1,55$ & 1.70 & 0.10 & 746.05 & - & A90/2823 & $807 \mathrm{C}-50 \mathrm{R}-1,21$ & 2.42 & -2.23 & 1155.41 & - \\
\hline A $90 / 2752$ & $807 A-80 X-1,53$ & 1.44 & -0.21 & 755.73 & - & A90/2824 & $807 \mathrm{C}-51 \mathrm{R}-1,21$ & 3.04 & -1.95 & 1160.41 & - \\
\hline A90/2753 & $807 \mathrm{~A}-80 \mathrm{X}-2,55$ & 1.59 & 0.07 & 757.25 & - & A90/2825 & $807 \mathrm{C}-51 \mathrm{R}-2,23$ & 3.31 & -1.99 & 1161.93 & - \\
\hline A90/2754 & $807 \mathrm{~A}-80 \mathrm{X}-3,55$ & 1.29 & 0.08 & 758.75 & - & A90/2826 & $807 C-51 R-3,119$ & 3.13 & -1.82 & 1164.39 & - \\
\hline A90/2755 & $807 A-81 X-1,61$ & 1.61 & -0.25 & 765.51 & - & A90/2827 & $807 \mathrm{C}-51 \mathrm{R}-4,39$ & 3.42 & -2.04 & 1165.09 & - \\
\hline A90/2756 & $807 \mathrm{~A}-82 \mathrm{X}-1,75$ & 1.81 & 0.16 & 775.25 & - & A90/2828 & $807 \mathrm{C}-52 \mathrm{R}-1,20$ & 3.52 & -2.18 & 1170.00 & - \\
\hline A90/2757 & $807 A-82 X-2,75$ & 1.86 & 0.07 & 776.75 & - & A90/2829 & $807 C-52 R-2,20$ & 3.25 & -1.97 & 1171.50 & - \\
\hline A90/2758 & $807 A-82 X-3,77$ & 1.87 & 0.04 & 778.27 & - & A $90 / 2830$ & $807 C-52 R-3,19$ & 3.14 & -1.81 & 1172.99 & - \\
\hline A90/2759 & $807 \mathrm{~A}-82 \mathrm{X}-3,79$ & 1.98 & 0.04 & 778.29 & - & A $90 / 2831$ & $807 C-53 R-1,20$ & 2.54 & -1.71 & 1179.60 & - \\
\hline A $90 / 2760$ & $807 \mathrm{~A}-82 \mathrm{X}-4,79$ & 1.58 & 0.15 & 779.79 & - & A $90 / 2832$ & $807 C-53 R-2,20$ & 1.74 & -1.54 & 1181.10 & - \\
\hline $\mathrm{A} 90 / 2761$ & $807 \mathrm{~A}-83 \mathrm{X}-1,60$ & 1.59 & 0.11 & 784.80 & - & A $90 / 2833$ & $807 \mathrm{C}-53 \mathrm{R}-3,20$ & 1.74 & -1.77 & 1182.60 & - \\
\hline A $90 / 2762$ & $807 A-83 X-2,60$ & 1.83 & 0.23 & 786.30 & - & A90/2834 & $807 C-53 R-4,20$ & 1.79 & -1.37 & 1184.07 & - \\
\hline A90/2763 & $807 A-83 X-3,60$ & 1.82 & -0.03 & 787.80 & - & A90/1936 & $807 \mathrm{C}-54 \mathrm{R}-1,0$ & 1.37 & -1.73 & 1188.80 & 65.73 \\
\hline A90/2764 & $807 A-83 X-4,60$ & 1.73 & 0.14 & 789.30 & - & A90/1937 & $807 \mathrm{C}-54 \mathrm{R}-1,15$ & 1.34 & -1.76 & 1188.95 & 65.74 \\
\hline A90/2765 & $807 C-2 R-1,73$ & 1.69 & 0.04 & 790.43 & - & A90/1938 & $807 C-54 R-1,26$ & 1.28 & -1.73 & 1189.06 & 65.75 \\
\hline A90/2766 & $807 \mathrm{C}-2 \mathrm{R}-2,73$ & 1.84 & -0.10 & 791.93 & - & A90/1939 & $807 \mathrm{C}-54 \mathrm{R}-1,35$ & 1.31 & -2.01 & 1189.15 & 65.76 \\
\hline A90/2767 & $807 A-84 X-1,60$ & 2.10 & -0.11 & 794.50 & - & A90/1940 & $807 \mathrm{C}-54 \mathrm{R}-1,47$ & 1.36 & -1.95 & 1189.27 & 65.77 \\
\hline A90/2768 & $807 A-84 X-2,60$ & 2.09 & -0.16 & 796.00 & - & A90/1941 & $807 C-54 \mathrm{R}-1,56$ & 1.44 & -1.60 & 1189.36 & 65.77 \\
\hline $\mathrm{A} 90 / 2769$ & $807 A-84 X-3,60$ & 2.29 & -0.07 & 797.50 & - & A90/1942 & $807 C-54 \mathrm{R}-1,68$ & 1.31 & -1.78 & 1189.48 & 65.78 \\
\hline A $90 / 2770$ & $807 \mathrm{~A}-84 \mathrm{X}-4,60$ & 2.32 & 0.00 & 799.00 & - & A $90 / 1943$ & $807 C-54 R-1,85$ & 1.74 & -1.51 & 1189.65 & 65.80 \\
\hline A90/2879 & $807 A-84 X-5,60$ & 2.24 & -0.01 & 800.50 & - & A90/1944 & $807 \mathrm{C}-54 \mathrm{R}-1,104$ & 1.35 & -1.69 & 1189.84 & 65.81 \\
\hline A90/2880 & $807 A-84 X-6,60$ & 2.26 & 0.11 & 802.00 & - & A90/1945 & $807 \mathrm{C}-54 \mathrm{R}-1,117$ & 1.30 & -1.76 & 1189.97 & 65.82 \\
\hline A90/2881 & $807 A-85 X-1,60$ & 2.01 & -0.09 & 804.20 & - & A90/1946 & $807 \mathrm{C}-54 \mathrm{R}-1,133$ & 1.30 & -1.80 & 1190.13 & 65.83 \\
\hline A90/2882 & $807 A-85 X-2,60$ & 2.20 & 0.10 & 805.70 & - & A90/1947 & $807 \mathrm{C}-54 \mathrm{R}-1,146$ & 1.60 & -1.13 & 1190.26 & 65.84 \\
\hline A90/2771 & $807 \mathrm{C}-4 \mathrm{R}-1,73$ & 1.53 & -0.06 & 809.73 & - & A90/1948 & $807 \mathrm{C}-54 \mathrm{R}-2,10$ & 1.47 & -1.75 & 1190.40 & 65.86 \\
\hline
\end{tabular}


Appendix (continued).

\begin{tabular}{|c|c|c|c|c|c|c|c|c|c|c|c|}
\hline Lab no. & $\begin{array}{l}\text { Hole, core, section, } \\
\text { interval }(\mathrm{cm})\end{array}$ & $\delta^{13} \mathrm{C}$ & $8^{18} \mathrm{O}$ & $\begin{array}{l}\text { Depth } \\
\text { (mbsf) }\end{array}$ & $\begin{array}{l}\text { Age } \\
\text { (Ma) }\end{array}$ & Lab no. & $\begin{array}{l}\text { Hole, core, section, } \\
\text { interval }(\mathrm{cm})\end{array}$ & $\delta^{13} \mathrm{C}$ & $\delta^{18} \mathrm{O}$ & $\begin{array}{l}\text { Depth } \\
\text { (mbsf) }\end{array}$ & $\begin{array}{l}\text { Age } \\
\text { (Ma) }\end{array}$ \\
\hline A90/1949 & $807 \mathrm{C}-54 \mathrm{R}-2,18$ & 1.56 & -1.26 & 1190.48 & 65.86 & A90/2348 & $807 \mathrm{C}-55 \mathrm{R}-3,85$ & 2.35 & -1.67 & 1200.75 & 66.67 \\
\hline A90/1950 & $807 \mathrm{C}-54 \mathrm{R}-2,32$ & 1.65 & -1.35 & 1190.62 & 65.87 & A90/2349 & $807 \mathrm{C}-55 \mathrm{R}-3,103$ & 2.45 & -1.72 & 1200.93 & 66.68 \\
\hline A90/1951 & $807 \mathrm{C}-54 \mathrm{R}-2,42$ & 1.86 & -1.51 & 1190.72 & 65.88 & A90/2350 & $807 \mathrm{C}-55 \mathrm{R}-3,112$ & 2.50 & -1.68 & 1201.02 & 66.69 \\
\hline A90/1952 & $807 \mathrm{C}-54 \mathrm{R}-2,55$ & 1.70 & -1.63 & 1190.85 & 65.89 & A90/2351 & $807 \mathrm{C}-55 \mathrm{R}-3,124$ & 2.52 & -1.57 & 1201.14 & 66.70 \\
\hline A90/1953 & $807 \mathrm{C}-54 \mathrm{R}-2,62$ & 2.02 & -0.78 & 1190.92 & 65.90 & A90/2352 & $807 \mathrm{C}-55 \mathrm{R}-3,133$ & 2.54 & -1.52 & 1201.23 & 66.71 \\
\hline A90/1954 & $807 \mathrm{C}-54 \mathrm{R}-2,73$ & 1.70 & -1.69 & 1191.03 & 65.90 & A $90 / 2353$ & $807 \mathrm{C}-55 \mathrm{R}-3,143$ & 2.26 & -2.26 & 1201.33 & 66.72 \\
\hline A90/1955 & 807C-54R-2, 81 & 1.62 & -1.52 & 1191.11 & 65.91 & A90/2354 & $807 C-55 R-4,11$ & 2.39 & -1.83 & 1201.51 & 66.73 \\
\hline A90/1956 & $807 \mathrm{C}-54 \mathrm{R}-2,86$ & 1.65 & -1.49 & 1191.16 & 65.91 & A90/2355 & $807 C-55 R-4,21$ & 2.54 & -1.67 & 1201.61 & 66.74 \\
\hline A90/1957 & $807 \mathrm{C}-54 \mathrm{R}-2,101$ & 1.51 & -1.75 & 1191.31 & 65.93 & A90/2356 & $807 \mathrm{C}-55 \mathrm{R}-4,37$ & 2.72 & -1.67 & 1201.77 & 66.75 \\
\hline A90/1958 & $807 C-54 R-2,107$ & 1.56 & -1.69 & 1191.37 & 65.93 & A90/2357 & $807 \mathrm{C}-55 \mathrm{R}-4,49$ & 2.66 & -1.64 & 1201.89 & 66.76 \\
\hline A90/1959 & $807 \mathrm{C}-54 \mathrm{R}-2,117$ & 1.44 & -1.32 & 1191.47 & 65.94 & A90/2358 & $807 C-55 R-4,63$ & 2.67 & -1.76 & 1202.03 & 66.77 \\
\hline A90/1960 & $807 \mathrm{C}-54 \mathrm{R}-2,126$ & 1.42 & -1.45 & 1191.56 & 65.95 & A90/2359 & $807 C-55 R-4,73$ & 2.69 & -1.59 & 1202.13 & 66.78 \\
\hline A90/1961 & $807 \mathrm{C}-54 \mathrm{R}-2,138$ & 1.71 & -1.71 & 1191.68 & 65.96 & A90/2360 & $807 C-55 R-4,85$ & 2.85 & -1.58 & 1202.25 & 66.79 \\
\hline A90/1962 & $807 \mathrm{C}-54 \mathrm{R}-2,149$ & 1.78 & -1.72 & 1191.79 & 65.96 & A90/2361 & $807 C-55 R-4,98$ & 2.75 & -1.72 & 1202.38 & 66.80 \\
\hline A90/1963 & $807 \mathrm{C}-54 \mathrm{R}-3,12$ & 1.75 & -1.87 & 1191.92 & 65.97 & A90/2380 & $807 \mathrm{C}-55 \mathrm{R}-4,110$ & 2.45 & -2.03 & 1202.50 & 66.81 \\
\hline A90/1964 & $807 \mathrm{C}-54 \mathrm{R}-3,22$ & 1.34 & -1.66 & 1192.02 & 65.98 & A90/2381 & $807 \mathrm{C}-55 \mathrm{R}-4,120$ & 2.54 & -1.86 & 1202.60 & 66.82 \\
\hline A90/1965 & $807 \mathrm{C}-54 \mathrm{R}-3,32$ & 1.25 & -1.68 & 1192.12 & 65.99 & A90/2382 & $807 \mathrm{C}-55 \mathrm{R}-4,130$ & 2.64 & -1.91 & 1202.70 & 66.82 \\
\hline A90/1966 & $807 \mathrm{C}-54 \mathrm{R}-3,44$ & 1.21 & -1.84 & 1192.24 & 66.00 & A90/2383 & $807 C-55 R-4,141$ & 2.67 & -1.72 & 1202.81 & 66.83 \\
\hline A90/1967 & $807 \mathrm{C}-54 \mathrm{R}-3,53$ & 1.14 & -1.55 & 1192.33 & 66.01 & A90/2835 & $807 \mathrm{C}-56 \mathrm{R}-1,20$ & 2.75 & -1.81 & 1206.80 & 67.15 \\
\hline A90/1968 & $807 \mathrm{C}-54 \mathrm{R}-3,67$ & 1.29 & -1.68 & 1192.47 & 66.02 & A90/2836 & $807 \mathrm{C}-56 \mathrm{R}-2,20$ & 2.87 & -1.64 & 1208.30 & 67.26 \\
\hline A90/1969 & $807 \mathrm{C}-54 \mathrm{R}-3,75$ & 1.49 & -1.64 & 1192.55 & 66.02 & A90/2837 & $807 C-56 R-3,20$ & 2.79 & -1.75 & 1209.80 & 67.38 \\
\hline A90/1970 & $807 \mathrm{C}-54 \mathrm{R}-3,88$ & 1.51 & -1.69 & 1192.68 & 66.03 & A90/2838 & $807 \mathrm{C}-57 \mathrm{R}-1,21$ & 3.01 & -1.60 & 1216.51 & 67.91 \\
\hline A90/1971 & $807 \mathrm{C}-54 \mathrm{R}-3,97$ & 1.59 & -1.83 & 1192.77 & 66.04 & A90/2839 & $807 \mathrm{C}-57 \mathrm{R}-2,21$ & 3.03 & -1.77 & 1218.01 & - \\
\hline A90/1972 & $807 \mathrm{C}-54 \mathrm{R}-3,106$ & 1.37 & -1.72 & 1192.86 & 66.05 & A90/2840 & $807 \mathrm{C}-58 \mathrm{R}-1,20$ & 3.09 & -1.69 & 1222.70 & - \\
\hline A90/1973 & $807 \mathrm{C}-54 \mathrm{R}-3,116$ & 1.47 & -1.14 & 1192.96 & 66.06 & A90/2841 & $807 \mathrm{C}-59 \mathrm{R}-1,34$ & 2.85 & -1.61 & 1232.54 & - \\
\hline A90/2014 & $807 \mathrm{C}-54 \mathrm{R}-3,122$ & 1.03 & -1.74 & 1193.02 & 66.06 & A90/2842 & $807 \mathrm{C}-59 \mathrm{R}-2,46$ & 2.92 & -1.65 & 1234.16 & - \\
\hline A90/2015 & $807 \mathrm{C}-54 \mathrm{R}-3,132$ & 1.33 & -1.61 & 1193.12 & 66.07 & A90/2844 & $807 \mathrm{C}-61 \mathrm{R}-1,110$ & 2.96 & -1.73 & 1252.60 & - \\
\hline A90/2016 & $807 \mathrm{C}-54 \mathrm{R}-3,139$ & 1.36 & -1.93 & 1193.19 & 66.07 & A90/2865 & $807 \mathrm{C}-61 \mathrm{R}-2,112$ & 2.95 & -1.70 & 1254.12 & - \\
\hline A90/2017 & $807 \mathrm{C}-54 \mathrm{R}-3,149$ & 1.33 & -1.86 & 1193.29 & 66.08 & A90/2384 & $807 \mathrm{C}-62 \mathrm{R}-1,35$ & 2.87 & -1.68 & 1261.55 & - \\
\hline A90/2018 & $807 C-54 R-4.9$ & 1.64 & -1.68 & 1193.39 & 66.09 & A90/2385 & $807 \mathrm{C}-62 \mathrm{R}-2,34$ & 2.92 & -1.51 & 1263.04 & - \\
\hline A90/2019 & $807 \mathrm{C}-54 \mathrm{R}-4,20$ & 1.60 & -1.72 & 1193.50 & 66.10 & A90/2386 & $807 \mathrm{C}-62 \mathrm{R}-3,41$ & 2.90 & -1.77 & 1264.61 & - \\
\hline A90/2020 & $807 \mathrm{C}-54 \mathrm{R}-4,31$ & 1.60 & -1.95 & 1193.61 & 66.11 & A90/2387 & $807 \mathrm{C}-63 \mathrm{R}-1,81$ & 3.04 & -1.47 & 1271.61 & - \\
\hline A90/2021 & $807 \mathrm{C}-54 \mathrm{R}-4,40$ & 1.22 & -1.81 & 1193.70 & 66.11 & A90/2388 & $807 \mathrm{C}-63 \mathrm{R}-2,81$ & 3.01 & -1.51 & 1273.11 & - \\
\hline A90/2022 & $807 \mathrm{C}-54 \mathrm{R}-4,50$ & 1.75 & -1.72 & 1193.80 & 66.12 & A90/2389 & $807 C-63 R-3,81$ & 2.98 & -1.76 & 1274.61 & - \\
\hline A90/2023 & $807 \mathrm{C}-54 \mathrm{R}-4,62$ & 1.64 & -1.87 & 1193.92 & 66.13 & A90/2390 & $807 \mathrm{C}-63 \mathrm{R}-4,85$ & 3.01 & -1.44 & 1276.15 & - \\
\hline A90/2024 & $807 \mathrm{C}-54 \mathrm{R}-4,80$ & 1.81 & -1.74 & 1194.10 & 66.15 & A90/2391 & $807 \mathrm{C}-64 \mathrm{R}-1,121$ & 3.01 & -1.67 & 1281.71 & - \\
\hline A90/2025 & $807 \mathrm{C}-54 \mathrm{R}-4,90$ & 1.70 & -1.85 & 1194.20 & 66.15 & A90/2392 & $807 \mathrm{C}-64 \mathrm{R}-2,121$ & 2.97 & -1.72 & 1283.21 & - \\
\hline A90/2026 & $807 \mathrm{C}-54 \mathrm{R}-4,100$ & 1.52 & -1.46 & 1194.30 & 66.16 & A90/2393 & $807 \mathrm{C}-64 \mathrm{R}-3,39$ & 2.88 & -1.74 & 1283.89 & - \\
\hline A90/2027 & $807 \mathrm{C}-54 \mathrm{R}-4,113$ & 1.69 & -1.76 & 1194.43 & 66.17 & A90/2394 & $807 \mathrm{C}-65 \mathrm{R}-1,58$ & 3.01 & -1.80 & 1290.68 & - \\
\hline A90/2028 & $807 \mathrm{C}-54 \mathrm{R}-4,125$ & 1.83 & -1.86 & 1194.55 & 66.18 & A90/2395 & $807 \mathrm{C}-65 \mathrm{R}-2,60$ & 3.10 & -1.67 & 1292.20 & - \\
\hline A90/2029 & $807 \mathrm{C}-54 \mathrm{R}-4,135$ & 1.84 & -1.10 & 1194.65 & 66.19 & A90/2396 & $807 \mathrm{C}-66 \mathrm{R}-1,55$ & 3.17 & -1.71 & 1300.35 & - \\
\hline A90/2030 & $807 \mathrm{C}-54 \mathrm{R}-4,148$ & 1.76 & -1.65 & 1194.78 & 66.20 & A90/2397 & $807 \mathrm{C}-66 \mathrm{R}-2,55$ & 3.14 & -1.74 & 1301.85 & - \\
\hline A90/2031 & $807 \mathrm{C}-55 \mathrm{R}-1,7$ & 1.89 & -1.60 & 1196.97 & 66.37 & A90/2398 & $807 \mathrm{C}-66 \mathrm{R}-3,55$ & 3.08 & -1.83 & 1303.35 & - \\
\hline A90/2032 & $807 \mathrm{C}-55 \mathrm{R}-1,17$ & 2.05 & -1.81 & 1197.07 & 66.38 & A90/2399 & $807 \mathrm{C}-67 \mathrm{R}-1,132$ & 2.92 & -1.86 & 1310.82 & - \\
\hline A90/2033 & $807 \mathrm{C}-55 \mathrm{R}-1,26$ & 2.20 & -1.51 & 1197.16 & 66.39 & A90/2400 & $807 \mathrm{C}-67 \mathrm{R}-2,132$ & 2.98 & -1.76 & 1312.26 & - \\
\hline A90/2034 & $807 \mathrm{C}-55 \mathrm{R}-1,35$ & 2.06 & -1.89 & 1197.25 & 66.39 & A90/2401 & $807 \mathrm{C}-67 \mathrm{R}-3,132$ & 2.97 & -1.82 & 1313.76 & - \\
\hline A90/2035 & 807C-55R-1, 49 & 2.08 & -1.80 & 1197.39 & 66.41 & A90/2402 & $807 \mathrm{C}-67 \mathrm{R}-4,125$ & 3.04 & -1.72 & 1315.19 & - \\
\hline A90/2036 & $807 \mathrm{C}-55 \mathrm{R}-1,65$ & 2.10 & -1.62 & 1197.55 & 66.42 & A90/2403 & $807 \mathrm{C}-67 \mathrm{R}-5,47$ & 2.94 & -1.83 & 1315.91 & - \\
\hline A90/2037 & $807 \mathrm{C}-55 \mathrm{R}-1,76$ & 2.00 & -1.75 & 1197.66 & 66.43 & A90/2404 & $807 \mathrm{C}-68 \mathrm{R}-1,77$ & 2.92 & -1.79 & 1319.87 & - \\
\hline A90/2039 & 807C-55R-1, 97 & 2.04 & -1.78 & 1197.87 & 66.44 & A90/2405 & $807 \mathrm{C}-68 \mathrm{R}-2,50$ & 3.04 & -1.68 & 1321.10 & - \\
\hline A90/2041 & $807 \mathrm{C}-55 \mathrm{R}-1,118$ & 2.03 & -1.81 & 1198.08 & 66.46 & A90/2406 & $807 \mathrm{C}-68 \mathrm{R}-3,26$ & 3.07 & -1.66 & 1322.36 & - \\
\hline A90/2042 & $807 \mathrm{C}-55 \mathrm{R}-2,12$ & 2.04 & -1.91 & 1198.52 & 66.49 & A90/2407 & $807 \mathrm{C}-69 \mathrm{R}-1,58$ & 3.05 & -1.71 & 1329.38 & - \\
\hline A90/2043 & $807 \mathrm{C}-55 \mathrm{R}-2,22$ & 2.01 & -1.74 & 1198.62 & 66.50 & A90/2408 & $807 \mathrm{C}-69 \mathrm{R}-2,56$ & 3.04 & -1.76 & 1330.86 & - \\
\hline A90/2045 & $807 \mathrm{C}-55 \mathrm{R}-2,34$ & 2.27 & -1.69 & 1198.74 & 66.51 & A90/2409 & $807 \mathrm{C}-69 \mathrm{R}-3,57$ & 3.07 & -1.70 & 1332.37 & - \\
\hline A90/2046 & $807 \mathrm{C}-55 \mathrm{R}-2,43$ & 2.10 & -1.57 & 1198.83 & 66.52 & A90/2487 & $807 \mathrm{C}-69 \mathrm{R}-4,65$ & 3.07 & -1.97 & 1333.95 & - \\
\hline A90/2047 & $807 \mathrm{C}-55 \mathrm{R}-2,50$ & 2.17 & -1.80 & 1198.90 & 66.52 & A90/2488 & $807 \mathrm{C}-69 \mathrm{R}-5,70$ & 3.17 & -1.85 & 1335.50 & - \\
\hline A90/2048 & $807 \mathrm{C}-55 \mathrm{R}-2,56$ & 2.20 & -1.67 & 1198.96 & 66.53 & A90/2489 & $807 \mathrm{C}-70 \mathrm{R}-1,46$ & 3.15 & -2.03 & 1338.86 & - \\
\hline A90/2049 & $807 \mathrm{C}-55 \mathrm{R}-2,64$ & 2.23 & -1.66 & 1199.04 & 66.54 & A90/2490 & $807 \mathrm{C}-70 \mathrm{R}-2,89$ & 3.25 & -1.89 & 1340.79 & - \\
\hline A90/2050 & $807 \mathrm{C}-55 \mathrm{R}-2,77$ & 2.20 & -1.47 & 1199.17 & 66.55 & A90/2491 & $807 \mathrm{C}-70 \mathrm{R}-3,9$ & 3.21 & -1.95 & 1341.49 & - \\
\hline A90/2342 & $807 \mathrm{C}-55 \mathrm{R}-3,12$ & 2.25 & -1.68 & 1200.02 & 66.61 & A90/2492 & $807 \mathrm{C}-70 \mathrm{R}-4,75$ & 3.22 & -1.94 & 1343.65 & - \\
\hline A90/2343 & $807 \mathrm{C}-55 \mathrm{R}-3,30$ & 2.31 & -1.60 & 1200.20 & 66.63 & A90/2493 & $807 \mathrm{C}-70 \mathrm{R}-5,28$ & 3.19 & -1.77 & 1344.68 & - \\
\hline A90/2344 & $807 \mathrm{C}-55 \mathrm{R}-3,38$ & 2.24 & -1.68 & 1200.28 & 66.63 & A90/2494 & $807 \mathrm{C}-71 \mathrm{R}-1,67$ & 3.17 & -1.85 & 1348.67 & - \\
\hline A90/2346 & $807 \mathrm{C}-55 \mathrm{R}-3,51$ & 2.33 & -1.83 & 1200.41 & 66.64 & A90/2495 & $807 \mathrm{C}-71 \mathrm{R}-2,36$ & 3.10 & -2.02 & 1349.86 & - \\
\hline A90/2345 & $807 \mathrm{C}-55 \mathrm{R}-3,59$ & 2.36 & -1.73 & 1200.49 & 66.65 & A90/2496 & $807 \mathrm{C}-71 \mathrm{R}-3,28$ & 3.12 & -1.84 & 1351.28 & - \\
\hline A90/2347 & $807 \mathrm{C}-55 \mathrm{R}-3,71$ & 2.46 & -1.56 & 1200.61 & 66.66 & & & & & & \\
\hline
\end{tabular}

